\title{
Sphinganine-Analog Mycotoxins (SAMs): Chemical Structures, Bioactivities, and Genetic Controls
}

\author{
Jia Chen ${ }^{1}$, Zhimin Li ${ }^{1}$, Yi Cheng ${ }^{1}\left(\mathbb{D}\right.$, Chunsheng Gao ${ }^{1}$, Litao Guo ${ }^{1}$, Tuhong Wang ${ }^{1}$ \\ and Jianping $\mathrm{Xu}^{1,2, * \mathbb{D}}$ \\ 1 Institute of Bast Fiber Crops and Center of Southern Economic Crops, \\ Chinese Academy of Agricultural Sciences, Changsha 410205, China; chenjia01@caas.cn (J.C.); \\ lizhimin@caas.cn (Z.L.); chengyi@caas.cn (Y.C.); gaochunsheng@caas.cn (C.G.); guolitao@caas.cn (L.G.); \\ wangtuhong@caas.cn (T.W.) \\ 2 Department of Biology, McMaster University, Hamilton, ON L8S 4K1, Canada \\ * Correspondence: jpxu@mcmaster.ca
}

Received: 31 October 2020; Accepted: 22 November 2020; Published: 24 November 2020

\begin{abstract}
Sphinganine-analog mycotoxins (SAMs) including fumonisins and A. alternata f. sp. Lycopersici (AAL) toxins are a group of related mycotoxins produced by plant pathogenic fungi in the Fusarium genus and in Alternaria alternata f. sp. Lycopersici, respectively. SAMs have shown diverse cytotoxicity and phytotoxicity, causing adverse impacts on plants, animals, and humans, and are a destructive force to crop production worldwide. This review summarizes the structural diversity of SAMs and encapsulates the relationships between their structures and biological activities. The toxicity of SAMs on plants and animals is mainly attributed to their inhibitory activity against the ceramide biosynthesis enzyme, influencing the sphingolipid metabolism and causing programmed cell death. We also reviewed the detoxification methods against SAMs and how plants develop resistance to SAMs. Genetic and evolutionary analyses revealed that the FUM (fumonisins biosynthetic) gene cluster was responsible for fumonisin biosynthesis in Fusarium spp. Sequence comparisons among species within the genus Fusarium suggested that mutations and multiple horizontal gene transfers involving the FUM gene cluster were responsible for the interspecific difference in fumonisin synthesis. We finish by describing methods for monitoring and quantifying SAMs in food and agricultural products.
\end{abstract}

Keywords: sphinganine-analog mycotoxins; fumonisins; AAL-toxin; chemical structure; toxicity; genetics and evolution; biosynthesis

\section{Introduction}

Mycotoxins are secondary metabolites produced by various fungi. These metabolites have important ecological functions on living systems in their natural habitats. As secondary metabolites, mycotoxins are regarded as not essential for fungal growth or reproduction. However, their toxic effects to plants, animals, as well as humans are attracting increasing attention from chemists, biologists, food scientists, and healthcare professionals. Many fungi are capable of synthesizing mycotoxins, including certain saprophytic molds, poisonous mushrooms, human fungal pathogens, and plant fungal pathogens. Mycotoxins produced by plant pathogenic fungi can be divided into two groups: (i) host-selective (or host-specific) toxins (HSTs) and (ii) non-host-specific toxins (nHSTs), depending on whether they are specifically toxic to host plant (HSTs) or to a wide range of species (nHSTs). The known mycotoxins are typically low molecular-weight chemicals but with diverse structures and modes of actions. One group of mycotoxins are structurally analogous to sphingosine, the backbone precursor of sphingolipids that play essential structural and cellular roles in eukaryotic cells. These toxins are called 
sphinganine-analog mycotoxins (SAMs), with fumonisins and the Alternaria alternata f. sp. Lycopersici (AAL) toxins as the two most widely studied groups of SAMs. SAMs are toxic to plants and animals. They act by inhibiting the ceramide synthase (CerS), thereby influencing the sphingolipid metabolism and initiating apoptosis in animals and programmed cell death (PCD) in plants [1-3]. The objective of this paper is to provide an updated review on the structural diversity, syntheses, modes of action, and health impacts of SAMs.

The discovery of fumonisin was first reported in 1988 and the organism producing it was Fusarium verticillioides (syn. Gibberella fujikuroi mating population A, syn. G. moniliformis Wineland, syn. F. moniliforme Sheldon) [4]. Fumonisins have since been found to be produced by at least 18 species of the Fusarium genus, with F. verticillioides and F. proliferatum being the most prominent, and by three unrelated fungal genera, Aspergillus section Nigri (such as Asp. niger, Asp. Welwitschiae (syn. Asp. awamori) and so on, known as black aspergilli), Tolypocladium (T. inflatum, T. cylindrosporum, and T. geodes), and Alternaria (the tomato pathotype of A. alternata, formerly known as A. arborescens) [5-10]. Species of the Fusarium genus can be found as saprophytes in soil and as endophytes and pathogens of many plants worldwide. A common group of diseases caused by Fusarium pathogens is rotting that can happen to all tissues during all stages of plant development [11,12]. In addition, the Fusarium species can infect crops at the post-harvest period during storage [13]. The fungal propagules surviving in the soil can also infect new crop plants and can be carried to new fields by wind or by anthropogenic activities, such as when seedlings are transplanted [14]. Fusarium strains can synthesize fumonisins during all stages of their growth, including the saprophytic stage in the soil, during their pathogenesis, and as endophytes in different parts of plants, as well as during crop storage after harvest [15].

Fumonisins, as a nHST, are major contaminants of cereals and grains, including corn, rice, wheat, barley, rye, oat, millet, and products made based on these crops [16]. The consumption of food contaminated by fumonisins significantly increases health problems for humans, leading to a variety of cancers such as esophageal cancer and neurological defects $[17,18]$. For example, the International Agency for Research on Cancer (IARC) characterized fumonisin $\mathrm{FB}_{1}$ as a group $2 \mathrm{~B}$ carcinogens for humans [16]. Fumonisins can also cause diseases and adverse effects in other species, especially in livestock when the feeds are contaminated [19]. Well-known diseases in livestock caused by fumonisins include leukoencephalomalacia in horses and pulmonary edema syndrome in pigs [20,21].

Similar to fuminisins, the AAL-toxins include a family of structurally analogous metabolites. AAL-toxins are a group of HST produced by the ascomycete fungal pathogen A. alternata $\mathrm{f}$. sp. Lycopersici, the causal agent of tomato stem canker disease [22]. It should be noted that several other pathotypes of A. alternata could also produce other HSTs responsible for fungal pathogenesis on their specific host plants, respectively [23]. Unlike other HSTs produced by A. alternata, besides the susceptible tomato host, AAL-toxins can also affect many other weeds and crops of dicotyledonous species and at least 25 species of Solanaceae [24,25]. Furthermore, the tomato pathotype of A. alternata was also reported to produce fumonisins B (FBs) $[8,26]$. AAL-toxin and FBs were not only detected in the necrosis plant tissues and culture media inoculated by A. alternata but also in spores and mycelia of this pathogen [27]. However, AAL-toxin remains the only toxin as a pathogenicity factor for stem canker disease of sensitive tomato varieties, while fumonisins are toxigenic virulence factors [28].

Because of the adverse impacts of SAMs on animal and human health, these toxins are also attracting increasing attention from food inspectors and public health agencies. Over the last three decades, significant progress has been made in our understanding of SAMs. Our objectives of this review are to capture these developments on SAMs with regard to their chemical structural diversity, the relationship between structure and activity, PCD induction, detoxification, genetics and evolution of SAMs biosynthesis, and laboratory detections. 


\section{Chemical and Structural Properties}

\subsection{Chemical and Structural Properties of Sphingolipids}

SAMs have a distinct structural similarity to sphinganine (Figure 1). Sphinganine (dihydrosphingosine, DHS) is the simplest class of sphingolipids and has a backbone that consists of a linear aliphatic group with 18-carbon, an amino at $\mathrm{C}-2$, and two hydroxyls $(-\mathrm{OH})$ at $\mathrm{C}-1$ and $\mathrm{C}-3$, respectively. Phytosphingosine is obtained if a hydroxyl is introduced at C-4. Sphingosine consists of the sphinganine backbone but with a double bond at C-4. Ceramides are synthesized by linking an amide fatty acid at $\mathrm{C}-2$ of sphingosine. Ceramides is a waxy lipid molecule, which is found in high concentrations in the membrane of eukaryotic cells. More complex sphingolipids can be formed by linking different chemical groups to hydroxyl (C1) of ceramides. Sphingolipids are one type of lipids widely found in their membranes in eukaryotes and a few prokaryotes, and they form complex and diverse interactions with other molecules [29]. Sphingolipids play important structural and functional roles, they are involved in a variety of signal transductions and crucial cellular processes [30,31]. For example, in humans, ceramides help form the skin's barrier and regulate immune response, protecting the skin against environmental irritants, pollutants, and water loss. Without the proper ratio of ceramides on our epidermal cells, the barrier of the skin will be damaged, resulting in dryness, itching, and irritation [32].

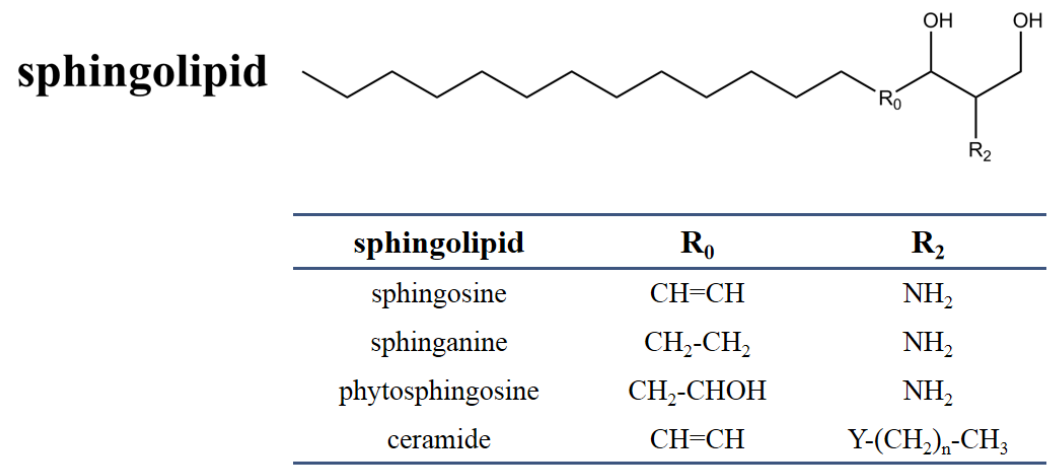

Figure 1. Chemical structure of sphingolipids. The table shows the different substituents in the chemical scaffold of the most essential sphingolipid.

\subsection{Chemical and Structural Properties of Fumonisins}

SAMs consist of two main types of toxins, fuminisins and AAL-toxins. Fumonisins can be divided into seven groups (FA, FB, FC, FD, FP, $\mathrm{FP}_{\mathrm{y}}$, and $\mathrm{FL}_{\mathrm{a}}$ ). These groups differ in the nitrogen functional group and the length of the carbon backbone [5]. Most fumonisins contain a 19-20 (FD contain 17 or 18 carbon) linear backbone similar to sphinganine with one nitrogen functional group (except for $\mathrm{FP}_{\mathrm{y}} \mathrm{s}$ and $\mathrm{FL}_{\mathrm{a}} \mathrm{s}$ ), two to four hydroxyl, two methyl, and two propane-1,2,3-tricarboxylic acid (PTCA) side chains esterified to the backbones [26,33]. The structural features of the seven groups of fumonisins are shown in Figure 2. Among them, the B group is the dominant one. For example, $\mathrm{FB}_{1}$ accounts for $70-80 \%$ of the total fumonisins produced by $F$. verticillioides and is the predominant toxic form [5]. $\mathrm{FB}_{2}$ and $\mathrm{FB}_{3}$ are isomers of each other but with one less hydroxyl group than $\mathrm{FB}_{1}$. The $\mathrm{B}$ series of fumonisins (FBs) are also the main food contaminants. Group A fumonisins (FA) are acetylated derivates of group B toxins, with lower toxicity and bioactivity than their FB counterparts [34]. Group C fumonisins $\left(\mathrm{FC}\right.$ ) have the same nitrogen functional group as $\mathrm{FB}_{1}$ but lack the terminal methyl group at $\mathrm{C}-1$ [35]. Three forms of acetylated $\mathrm{FC}_{1}$ have been discovered in F. oxysporum [36]. Group P fumonisins (FP) have a nitrogen functional group of 3-hydroxypyridinium instead of the amino group in FB at the $\mathrm{R}_{2}$ position [37]. The FC and FP groups have similar phytotoxic and cytotoxic effects to those caused by $\mathrm{FB}_{1}$ or AAL-toxin [38]. Aside from these four main groups, there are several other lesser-known fumonisin analogs, with one or two PTCA replaced by a hydroxyl or carbonyl or other carboxylic acids group at C-13 and/or C-14 of the backbone (for example, $\mathrm{HFB}_{1}$, as show in 
Figure 2). Rheeder et al. summarized the 28 fumonisin analogs that have been characterized between 1988 and 2002 [5]. By reversed-phase high-performance liquid chromatography/electrospray ionization ion trap multistage mass spectrometry (RP-HPLC/ESI-IT-MS ${ }^{n}$ ), Bartok et al. detected 58 fumonisins (including FD) or fumonisin-like compounds from F. verticillioides in rice cultures, and 28 isomers of $\mathrm{FB}_{1}[33,39]$. Indeed, the recent application of a semi-targeted method revealed over 100 structurally related compounds from SAMs-producing fungi, including a hydroxyl- $\mathrm{FB}_{1}$, and two new classes of non-aminated fumonisins $\left(\mathrm{FP}_{\mathrm{y}} \mathrm{s}\right.$ and $\left.\mathrm{FL}_{\mathrm{a}} \mathrm{s}\right)[26]$.

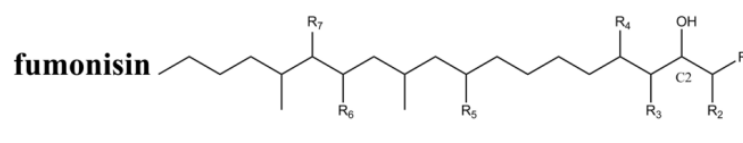

Panel A

AAL-toxin

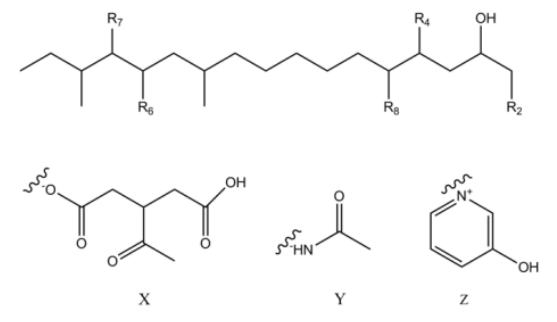

\begin{tabular}{cccccc}
\hline AAL-toxin & $\mathbf{R}_{2}$ & $\mathbf{R}_{4}$ & $\mathbf{R}_{8}$ & $\mathbf{R}_{6}$ & $\mathbf{R}_{7}$ \\
\hline $\mathrm{TA}_{1}$ & $\mathrm{NH}_{2}$ & $\mathrm{OH}$ & $\mathrm{OH}$ & $\mathrm{X}$ & $\mathrm{H}$ \\
$\mathrm{TA}_{2}$ & $\mathrm{NH}_{2}$ & $\mathrm{OH}$ & $\mathrm{OH}$ & $\mathrm{H}$ & $\mathrm{X}$ \\
$\mathrm{TB}_{1}$ & $\mathrm{NH}_{2}$ & $\mathrm{OH}$ & $\mathrm{H}$ & $\mathrm{X}$ & $\mathrm{H}$ \\
$\mathrm{TB}_{2}$ & $\mathrm{NH}_{2}$ & $\mathrm{OH}$ & $\mathrm{H}$ & $\mathrm{H}$ & $\mathrm{X}$ \\
$\mathrm{TC}_{1}$ & $\mathrm{NH}_{2}$ & $\mathrm{H}$ & $\mathrm{H}$ & $\mathrm{X}$ & $\mathrm{H}$ \\
$\mathrm{TC}_{2}$ & $\mathrm{NH}_{2}$ & $\mathrm{H}$ & $\mathrm{H}$ & $\mathrm{H}$ & $\mathrm{X}$ \\
$\mathrm{TD}_{1}$ & $\mathrm{Y}$ & $\mathrm{OH}$ & $\mathrm{H}$ & $\mathrm{X}$ & $\mathrm{H}$ \\
$\mathrm{TD}_{2}$ & $\mathrm{Y}$ & $\mathrm{OH}$ & $\mathrm{H}$ & $\mathrm{H}$ & $\mathrm{X}$ \\
$\mathrm{TE}_{1}$ & $\mathrm{Y}$ & $\mathrm{H}$ & $\mathrm{H}$ & $\mathrm{X}$ & $\mathrm{H}$ \\
$\mathrm{TE}_{2}$ & $\mathrm{Y}$ & $\mathrm{H}$ & $\mathrm{H}$ & $\mathrm{H}$ & $\mathrm{X}$ \\
\hline
\end{tabular}

Panel B

\begin{tabular}{|c|c|c|c|c|c|c|}
\hline fumonisin & $\mathrm{R}_{1}$ & $\mathbf{R}_{2}$ & $\mathbf{R}_{3}$ & $\mathbf{R}_{4}$ & $\mathbf{R}_{5}$ & $\mathbf{R}_{6}=\mathbf{R}_{7}$ \\
\hline $\mathrm{FA}_{1}$ & $\mathrm{CH}_{3}$ & $\mathrm{Y}$ & $\mathrm{H}$ & $\mathrm{OH}$ & $\mathrm{OH}$ & $\mathrm{X}$ \\
\hline $\mathrm{FA}_{2}$ & $\mathrm{CH}_{3}$ & Y & $\mathrm{H}$ & $\mathrm{OH}$ & $\mathrm{H}$ & $\mathrm{x}$ \\
\hline $\mathrm{FA}_{3}$ & $\mathrm{CH}_{3}$ & Y & $\mathrm{H}$ & $\mathrm{H}$ & $\mathrm{OH}$ & $\mathrm{x}$ \\
\hline $\mathrm{FA}_{4}$ & $\mathrm{CH}_{3}$ & $\mathrm{Y}$ & $\mathrm{H}$ & $\mathrm{H}$ & $\mathrm{H}$ & $\mathrm{x}$ \\
\hline $\mathrm{isoFA}_{\mathrm{la}, \mathrm{b}}^{\mathrm{a}}$ & $\mathrm{CH}_{3}$ & $\mathrm{Y}$ & $\mathrm{H}$ & $\mathrm{H}$ & $\mathrm{H}$ & $\mathrm{x}$ \\
\hline $\mathrm{FC}_{1}$ & $\mathrm{H}$ & $\mathrm{NH}_{2}$ & $\mathrm{H}$ & $\mathrm{OH}$ & $\mathrm{OH}$ & $\mathrm{x}$ \\
\hline $\mathrm{FC}_{2}$ & $\mathrm{H}$ & $\mathrm{NH}_{2}$ & $\mathrm{H}$ & $\mathrm{OH}$ & $\mathrm{H}$ & $\mathrm{x}$ \\
\hline $\mathrm{FC}_{3}$ & $\mathrm{H}$ & $\mathrm{NH}_{2}$ & $\mathrm{H}$ & $\mathrm{H}$ & $\mathrm{OH}$ & $x$ \\
\hline $\mathrm{FC}_{4}$ & $\mathrm{H}$ & $\mathrm{NH}_{2}$ & $\mathrm{H}$ & $\mathrm{H}$ & $\mathrm{H}$ & $\mathrm{x}$ \\
\hline isoFC $_{1}$ & $\mathrm{H}$ & $\mathrm{NH}_{2}$ & $\mathrm{OH}$ & $\mathrm{H}$ & $\mathrm{OH}$ & $\mathrm{x}$ \\
\hline $\mathrm{isoFC}_{2,3}^{\mathrm{b}}$ & $\mathrm{H}$ & $\mathrm{NH}_{2}$ & $\mathrm{H}$ & $\mathrm{H}$ & $\mathrm{H}$ & $\mathrm{x}$ \\
\hline $\mathrm{FC}_{1} \mathrm{OH}$ & $\mathrm{H}$ & $\mathrm{NH}_{2}$ & $\mathrm{OH}$ & $\mathrm{OH}$ & $\mathrm{OH}$ & $\mathrm{x}$ \\
\hline $\mathrm{FD}^{\mathrm{c}}$ & $\mathrm{H}$ & $\mathrm{NH}_{2}$ & $\mathrm{H}$ & $\mathrm{H}$ & $\mathrm{OH}$ & $\mathrm{x}$ \\
\hline $\mathrm{FP}_{1}$ & $\mathrm{CH}_{3}$ & Z & $\mathrm{H}$ & $\mathrm{OH}$ & $\mathrm{OH}$ & $\mathrm{x}$ \\
\hline $\mathrm{FP}_{2}$ & $\mathrm{CH}_{3}$ & z & $\mathrm{H}$ & $\mathrm{OH}$ & $\mathrm{H}$ & $\mathrm{x}$ \\
\hline $\mathrm{FP}_{3}$ & $\mathrm{CH}_{3}$ & $\mathrm{Z}$ & $\mathrm{H}$ & $\mathrm{H}$ & $\mathrm{OH}$ & $\mathrm{x}$ \\
\hline $\mathrm{FP}_{\mathrm{y} 2}$ & $\mathrm{CH}_{3}$ & $=\mathrm{O}$ & $\mathrm{H}$ & $\mathrm{OH}$ & $\mathrm{H}$ & $\mathrm{x}$ \\
\hline $\mathrm{FP}_{\mathrm{y} 4}$ & $\mathrm{CH}_{3}$ & $=\mathrm{O}$ & $\mathrm{H}$ & $\mathrm{H}$ & $\mathrm{H}$ & $\mathrm{x}$ \\
\hline $\mathrm{FP}_{\mathrm{y} 6}$ & $\mathrm{CH}_{3}$ & $=\mathrm{O}$ & $\mathrm{OH}$ & $\mathrm{OH}$ & $\mathrm{H}$ & $\mathrm{x}$ \\
\hline $\mathrm{FL}_{\mathrm{a} 2}$ & $\mathrm{CH}_{3}$ & $\mathrm{OH}$ & $\mathrm{H}$ & $\mathrm{OH}$ & $\mathrm{H}$ & $\mathrm{x}$ \\
\hline $\mathrm{FL}_{\mathrm{a4}}$ & $\mathrm{CH}_{3}$ & $\mathrm{OH}$ & $\mathrm{H}$ & $\mathrm{H}$ & $\mathrm{H}$ & $\mathrm{x}$ \\
\hline
\end{tabular}

\begin{tabular}{|c|c|c|c|c|c|c|}
\hline fumonisin B & $\mathrm{R}_{1}$ & $\mathbf{R}_{2}$ & $\mathbf{R}_{3}$ & $\mathbf{R}_{4}$ & $\mathbf{R}_{5}$ & $\mathbf{R}_{6}=\mathbf{R}_{7}$ \\
\hline $\mathrm{FB}_{1}$ & $\mathrm{CH}_{3}$ & $\mathrm{NH}_{2}$ & $\mathrm{H}$ & $\mathrm{OH}$ & $\mathrm{OH}$ & $\mathrm{x}$ \\
\hline $\mathrm{FB}_{2}$ & $\mathrm{CH}_{3}$ & $\mathrm{NH}_{2}$ & $\mathrm{H}$ & $\mathrm{OH}$ & $\mathrm{H}$ & $\mathrm{x}$ \\
\hline $\mathrm{FB}_{3}$ & $\mathrm{CH}_{3}$ & $\mathrm{NH}_{2}$ & $\mathrm{H}$ & $\mathrm{H}$ & $\mathrm{OH}$ & $\mathrm{x}$ \\
\hline $\mathrm{FB}_{4}$ & $\mathrm{CH}_{3}$ & $\mathrm{NH}_{2}$ & $\mathrm{H}$ & $\mathrm{H}$ & $\mathrm{H}$ & $\mathrm{x}$ \\
\hline $\mathrm{FB}_{6}$ & $\mathrm{CH}_{3}$ & $\mathrm{NH}_{2}$ & $\mathrm{OH}$ & $\mathrm{OH}$ & $\mathrm{H}$ & $\mathrm{x}$ \\
\hline isoFB $_{1}$ & $\mathrm{CH}_{3}$ & $\mathrm{NH}_{2}$ & $\mathrm{OH}$ & $\mathrm{H}$ & $\mathrm{OH}$ & $\mathrm{x}$ \\
\hline isoFB $_{\text {la-d }}^{b}$ & $\mathrm{CH}_{3}$ & $\mathrm{NH}_{2}$ & $\mathrm{H}$ & $\mathrm{H}$ & $\mathrm{OH}$ & $\mathrm{x}$ \\
\hline isoFB ${ }^{b}, 3 a-e$ & $\mathrm{CH}_{3}$ & $\mathrm{NH}_{2}$ & $\mathrm{H}$ & $\mathrm{H}$ & $\mathrm{H}$ & $\mathrm{x}$ \\
\hline $\mathrm{FB}_{5} /$ isoFBa $_{5 a-d}$ & $\mathrm{CH}_{3}$ & $\mathrm{NH}_{2}$ & H & $\mathrm{H}$ & $\mathrm{OH}$ & $\mathrm{x}$ \\
\hline $\mathrm{FB}_{1} \mathrm{OH}$ & $\mathrm{CH}_{3}$ & $\mathrm{NH}_{2}$ & $\mathrm{OH}$ & $\mathrm{OH}$ & $\mathrm{OH}$ & $\mathrm{x}$ \\
\hline $\mathrm{FBK}_{1} 2 \mathrm{TCA}^{\mathrm{d}}$ & $\mathrm{CH}_{3}$ & $\mathrm{NH}_{2}$ & $\mathrm{H}$ & $\mathrm{OH}$ & $\mathrm{OH}$ & $\mathrm{x}$ \\
\hline $\mathrm{FBK}_{4} 2 \mathrm{TCA}^{\mathrm{d}}$ & $\mathrm{CH}_{3}$ & $\mathrm{NH}_{2}$ & $\mathrm{H}$ & $\mathrm{OH}$ & $\mathrm{H}$ & $\mathrm{x}$ \\
\hline $\mathrm{HFB}_{1}$ & $\mathrm{CH}_{3}$ & $\mathrm{NH}_{2}$ & $\mathrm{H}$ & $\mathrm{OH}$ & $\mathrm{OH}$ & $\mathrm{OH}$ \\
\hline $\mathrm{PHFB}^{\mathrm{c}_{\mathrm{a}, \mathrm{b}}}$ & $\mathrm{CH}_{3}$ & $\mathrm{NH}_{2}$ & $\mathrm{H}$ & $\mathrm{OH}$ & $\mathrm{OH}$ & $\mathrm{x} / \mathrm{OH}$ \\
\hline
\end{tabular}

Figure 2. Chemical structure of sphinganine-analog mycotoxins (SAMs). Panel A shows the AAL-toxins, Panel B shows fumonisin. In the table of each panel, the different substituents present in the chemical scaffolds of individual compounds are shown.

\subsection{Chemical and Structural Properties of AAL-Toxin}

The AAL-toxins have a structural similarity to fumonisins (Figure 2). The main difference between fumonisins and AAL-toxins is that AAL-toxins have one fewer PTCA side chain than fumonisins. The AAL-toxins have been divided into five pairs based on their side chain structures: A, B, C, D, and E pairs (TA, TB, TC, TD and TE). These pairs differ in their nitrogen functional group and hydroxylation at C-4 or C-5 positions of the backbone [40-42]. Each pair of AAL-toxins is composed of two regioisomers 
with PTCA esterified to C-13 or C-14 of the backbone, respectively. The TA pair is the major pair of toxins, with the TB and TC pairs formed by removing hydroxyl groups one by one from C-5 and C-4 of the TA pair. The TD and TE pairs were acetylated derivatives of TB and TC respectively, while the acetylated form of TA and keto derivatives of AAL-toxins (2-keto or 14-keto analogues predicted) were also found in 2015 [26]. These four regioisomeric pairs (TB, TC, TD, and TE) of AAL-toxins can all induce genotype-specific necrosis characteristics in tomato leaflets in the same pattern as that of the TA pair, but they differ as much as 1000-fold in their relative toxicity [42].

\subsection{Chemical and Structural Properties of Analogs of SAMs}

In addition to fumonisins and AAL-toxins, several fungal secondary metabolites have also been identified as structural analogs of sphinganine and CerS inhibitors (summarized in Figure 3 and Table 1). These metabolites include myriocins, sphingofungins, viridiofungins, 2-amino-14,16-dimethyl-octadecan-3-ol (2-AOD-3-ol), and a new C17-SAM identified from mussels contaminated by marine fungi including Aspergillus, Fusarium, and Trichoderma. Australifungin, a structurally unrelated mycotoxin produced by Sporormiella australis, was also shown to inhibit sphingolipid synthesis in plants, similar to those of SAMs.

2-AOD-3-ol<smiles>CCC(C)CC(C)CCCCCCCCCC(O)C(C)N</smiles>

C17-SAMS

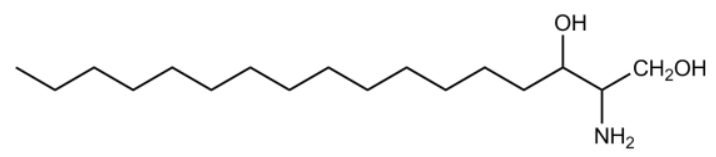

sphingofungin $\mathrm{B}$

myriocin<smiles>CCCCCCC(=O)CCCCCC/C=C/CC(O)C(O)C(N)(CO)C(=O)O</smiles><smiles>CCCCCCCCC(=O)CCCCCCC=CC(C(=O)NC(Cc1ccc(O)cc1)C(=O)O)C(O)(CO)C(=O)O</smiles>

Figure 3. Chemical structures of other sphinganine-analog metabolites.

Myriocins, sphingofungins, and viridiofungins inhibit serine palmitoyltransferase (SPT), while fumonisins, AAL-toxin, and australifungin inhibit sphinganine-N acyltransferase. Serine palmitoyl transferase, one of the key enzymes in the synthesis of sphingolipids, was also reported to play a positive role in PCD regulation. The increase of SPT activity promoted PCD in plants. In contrast, by inhibiting SPT activity, the excessive accumulation of sphingosine can be alleviated, leading to reduced PCD [43]. Therefore, myriocin are usually used as a SPT inhibitor to pretreat Arabidopsis thaliana and tomato plants to induce their resistance to $\mathrm{FB}_{1}$ and AAL-toxin, respectively [44,45]. 
Table 1. Analogs of sphinganine-analog mycotoxins (SAMs), their fungal producer(s), and their activities

\begin{tabular}{|c|c|c|c|c|c|}
\hline \multicolumn{2}{|c|}{ Analog of SAMs } & Fungi/Origin & Activities & $\begin{array}{l}\text { Scopus Citation } \\
\text { (Review) }\end{array}$ & Reference \\
\hline \multicolumn{2}{|c|}{$\begin{array}{c}\text { Myriocins } \\
\text { (thermozymocidin, ISP-I) }\end{array}$} & $\begin{array}{l}\text { Myriococcum albomyces } \\
\text { Melanconis flavovirens } \\
\text { Isaria sinclairii }\end{array}$ & $\begin{array}{c}\text { Antifungal activity } \\
\text { Inhibitor of serine palmitoyltransferase (SPT) } \\
\text { Immunosuppressive activity } \\
\text { Protective effect on hepatotoxicity } \\
\text { Relieve fumonisin } \mathrm{B}_{1}\left(\mathrm{FB}_{1}\right) \text {-induced toxicity and cell death } \\
\text { Multi-pharmacological function on human }\end{array}$ & $421(34)$ & {$[46-53]$} \\
\hline Sphingofungins & $\begin{array}{c}\mathrm{E} / \mathrm{F} \\
\mathrm{A} / \mathrm{B} / \mathrm{C} / \mathrm{D} / \mathrm{I} \\
\mathrm{G} / \mathrm{H}\end{array}$ & $\begin{array}{l}\text { Paecilomyces variotii } \\
\text { Asp. fumigatus } \\
\text { Asp. penicilliodes }\end{array}$ & $\begin{array}{l}\text { Inhibitor of SPT } \\
\text { Antifungal activity }\end{array}$ & $65(15)$ & {$[54-58]$} \\
\hline Viridiofungins & $\mathrm{A} / \mathrm{B} / \mathrm{C}$ & $\begin{array}{l}\text { Trichoderma viride Pers } \\
\text { Tri. harzianum }\end{array}$ & $\begin{array}{l}\text { Inhibitors of SPT and squalene synthase } \\
\text { Antifungal but lack antibacterial activity }\end{array}$ & $21(5)$ & [59-61] \\
\hline \multicolumn{2}{|c|}{ Australifungin } & Sporormiella australis & $\begin{array}{l}\text { Inhibitors of sphinganine-N acyl transferase } \\
\text { Antifungal activity, phytotoxicity }\end{array}$ & $26(7)$ & {$[62,63]$} \\
\hline \multicolumn{2}{|c|}{ 2-AOD-3-ol } & F. avenaceum & Animal cell toxicity as fumonisin B & 5 & [64] \\
\hline \multicolumn{2}{|c|}{ C17-sphinganine analog mycotoxin } & Contaminated mussels & Blocking skeletal muscle contraction & 1 & [65] \\
\hline
\end{tabular}




\section{Relationships between SAMs' Structure and Biological Activities}

The biological effects of SAMs, such as their toxicity, are similar among different SMAs. Many SAMs have a similar spectrum of susceptible plant species [34]. Tomato tissues and cells are similarly sensitive to AAL-toxins and to $\mathrm{FB}_{1}$ and $\mathrm{FB}_{2}$ toxins. In some other plants, $\mathrm{AAL}$-toxins can cause necrotic cell death, similar to that of fumonisins [66]. For animal tissue cultures, the TA toxins can induce cytotoxicity in both rat liver and dog kidney cells as $\mathrm{FB}_{1}$ toxin $[67,68]$. Besides, AAL-toxin and F. verticillioides could also inhibit larval growth and reduced pupal weights of tobacco budworrn Heliothis virescens [69]. Such similarities have been attributed to the structural similarities between the SAMs and sphinganine. However, there are differences among SAMs in their biological effects and those differences are related to their structural differences. Below, we summarize the main findings in this area.

The amino functional group of SAMs is essential for their toxic activity. The peracetylated derivatives of AAL-toxins and $\mathrm{FB}_{1}$ are biologically inactive or have significantly reduced toxicity in both the plant bioassay and the animal tissue culture systems [66,70,71]. These results were consistent with initial reports on these toxins showing that blocking the free primary amines of AAL-toxins by specific reagents could abolish the biological activities of these toxins in plants [72]. In an in vitro test of rat primary hepatocytes, it was noted that the $\mathrm{N}$-acetyl analogue of $\mathrm{FB}_{1}, \mathrm{FA}_{1}$, also showed CerS inhibition [68]. Later, FA was found to spontaneously undergo isomerization, rearranging its O-acetylation group to form different analogs. The impact of these rearrangement products on inhibition of CerS in rat liver slices also supported the important role of a primary amino for both CerS inhibition and toxicity [73]. Derivatization of the amino group with fluorogenic reagents also makes the FBs' detection possible by the high-performance liquid chromatography (HPLC) assay [74]. FBs can bind covalently to proteins by reacting with amino groups in abiogenic conversions, which may increase the toxicity of those conversion products [75]. Similarly, the terminal amino group of $\mathrm{FB}_{1}$ can conjugate to bovine serum albumin (BSA) and work as an immunogen to produce monoclonal antibodies for enzyme-linked immunosorbent assay (ELISA) detection [76]. Amino group of fumonisins can also work as an electron donor and react with the electrophilic carbon within the isothiocyanate (ITC) group. Consequently, FBs can be degraded by fumigation treatment with ITC-containing compounds [77].

The hydrolysis product of $\mathrm{FB}_{1}\left(\mathrm{HFB}_{1}\right)$ was shown as less toxic than both $\mathrm{FB}_{1}$ and $\mathrm{TA}$ to plants [78]. Neither $\mathrm{HFB}_{1}$ nor the yeast sphingolipids (completely acetylated) contain PTCA. While both had adverse effects on duckweed growth, they showed lower phytotoxicity than $\mathrm{TA}$ and $\mathrm{FB}_{1}$ that contained one and two PTCA, respectively [79]. In contrast, the hydrolysis products of AAL-toxins largely maintain the toxicities of their parental compounds to the susceptible tomato lines [66]. These results indicate that PTCA is important to phytotoxicity of FBs and there is specificity of interaction between AAL-toxins and tomatoes.

Different from those in plants, an in vitro test using primary hepatocytes of rat showed that the HFBs had greater cytotoxicity than FBs. However, the HFBs could not initiate cancer development due to the lack of PTCA moiety, which was proposed to play an active role in the fumonisins absorption from the gut [70]. In the pregnant $\mathrm{LM} / \mathrm{Bc}$ mouse model, $\mathrm{HFB}_{1}$ did not cause neural tube defects. In contrast, $10 \mathrm{mg}$ of $\mathrm{FB}_{1} / \mathrm{kg}$ body weight of mice disrupted maternal sphingolipid metabolism, caused hepatic apoptosis in the female mice, increased fetus mortality, and reduced fetus weight [80]. In the SAMs-sensitive pig model, $\mathrm{HFB}_{1}$ was shown to have limited intestinal or hepatic toxicity but only slightly disrupted sphingolipids metabolism [81]. The toxic effects of $\mathrm{FB}_{1}$ and $\mathrm{HFB}_{1}$ exposure on intestinal barrier function and immunity in a pig intestinal porcine epithelial cells and porcine peripheral blood mononuclear cells co-culture model was also investigated. $\mathrm{FB}_{1}$ aggravated lipopolysaccharide (LPS)/deoxynivalenol (DON)-induced intestinal inflammation, while $\mathrm{HFB}_{1}$ showed less toxicity to the immune system [82]. In addition, when $\mathrm{HFB}_{1}$ and $\mathrm{HFB}_{2}$ were acylated by CerS, the $\mathrm{N}$-acyl-metabolites were toxic in vitro to the human colonic cell line and in vivo to the intraperitoneal rat tissues [83].

Fumonisins are capable of binding to polysaccharides and proteins via their two PTCA side chains in thermal-treated food and form fumonisin artifacts [84]. The activities of SAMs vary depending on where hydroxylation occurs along the carbon backbone. For example, $\mathrm{FB}_{2}$ had a greater cytotoxic effect 
than $\mathrm{FB}_{3}$ and $\mathrm{FB}_{1}$ in primary rat hepatocytes [70]. However, different from most other side groups, the C-1 terminal methyl group, which differed between FC and AAL-toxin from other fumonisins, seemed not required for the biological activity in SAMs.

Similar symptoms but less phytotoxicities of SAMs were observed when long-chain sphingoid bases or simple sphingolipids were applied to duckweed, which indicated that the phytotoxicity of SAMs might be resulted from the accumulation of phytotoxic sphingolipid intermediates [71,85]. This result was consistent with the induction of PCD through ceramide-based signaling pathways (described below).

Although AAL-toxins and fumonisins are structurally related chemicals with similar phytotoxicity, the latter are 10 times less efficient. AAL-toxins have been considered to serve as an herbicide at a very low dosage against a wide variety of broadleaf weeds (e.g., jimsonweed, prickly sida, and black nightshade). However, monocotyledonous crops (e.g., maize, wheat, and resistant varieties of tomato) are tolerant to AAL-toxins $[24,86,87]$. Until 2013, the mode of action through CerS inhibition was not among the 21 molecular target sites of the commonly used herbicides. Using AAL-toxin as a lead compound has the potential to develop novel and safe bioherbicide, which has phytotoxicity but reduced or no mammalian toxicity $[88,89]$.

\section{Detoxification of SAMs}

Using agricultural and manufacturing practices for preventing the spread and growth of toxin-producing fungi and limiting mycotoxin production is the preferred method to eliminate food contamination by fungal toxins at the pre-harvest period [90]. However, it is extremely difficult to completely prevent fungal pathogen growth and mycotoxin contamination in agricultural practices and in food storage and processing. Since the toxicity of SAMs is structurally dependent, our knowledge on the relationships between SAMs' structure and biological activity provides clues for developing effective management strategies to minimize the impact of SAMs in food and feed products. Indeed, structural modifications such as hydrolysis have been demonstrated as effective at reducing the toxicity of SAMs [91].

Over the last three decades, chemical, biological, and physical strategies have been developed to degrade mycotoxins in food and feed products [92]. For example, nixtamalization was applied to reduce FBs by cooking fumonisin-contaminated maize with lime, as well as by using atmospheric ammoniation treatment [93-95]. Chlorine dioxide also showed the ability to degrade $\mathrm{FB}_{1}$ [96]. Two common cooking methods include extrusion and nixtamalization were shown to reduce the toxicity of $\mathrm{FB}_{1}$-contaminated corn [97]. Cold atmospheric pressure plasma was used as a physical treatment to successfully degrade pure $\mathrm{FB}_{1}$ and AAL-toxins within $60 \mathrm{~s}$, while the presence of the matrix slowed down the degradation $[98,99]$. Ozone was applied to disrupt fungal cells of Fusarium and Aspergillus by oxidizing sulfhydryl and amino acid groups of enzymes or attacking the polyunsaturated fatty acids of the cell wall [100]. However, not all SAMs are susceptible to physical and chemical treatments. In addition, some of these treatments may also result in derivatives with unknown toxicity and be detrimental for the treated commodities, as shown in some cases $[101,102]$.

Another method to reduce SAM toxicity is through microbial actions. Microorganisms can carry out biotransformation reactions to detoxify SAMs [91]. Such methods include deamination, acetylation, hydrolysis, glucosylation, and decarboxylation. For example, Benedetti et al. isolated a Gram-negative rod bacterial strain from soil capable of degrading fumonisin to four metabolites when fumonisin was supplied as the sole carbon source [103]. The bacterium Sphingopyxis sp. could detoxify fumonisin B1 by at least two enzymatic steps, including an initial de-esterification reaction followed by de-amination of hydrolyzed product [104]. Chlebicz and Śliżewska found that 12 strains of Lactobacillus sp. bacteria and 6 strains of Saccharomyces cerevisiae yeast could reduce the concentration of $\mathrm{FB}_{1}$ and $\mathrm{FB}_{2}$ by $40 \%$ [105]. Similarly, Burgess demonstrated that fumonisin-producing Asp. welwitschiae have the ability to produce enzymes to synthesize non-aminated fumonisins that are less toxic than FB, and that those enzymes could be used for fumonisin detoxification [106]. Indeed, using enzymes to detoxify by 
modification of chemical structures has become a promising method for mycotoxins control after grains harvest $[107,108]$. For example, fumD (carboxylesterase) from Sphingopyxis catalyze detoxification of $\mathrm{FB}_{1}$ to the hydrolyzed form by hydrolysis of both PTCA side chains. Then, the aminotransferase FumI could degrade $\mathrm{FB}_{1}$ by catalyzing the deamination of $\mathrm{HFB}_{1}$. FumD has also been tested for interference of fumonisins adsorption in turkey, swine, and pig [109-111]. Finally, several other enzymes such as manganese peroxidase from lignocellulose-degrading fungi and laccase from Pleurotus eryngii were all capable of degrading fumonisins [112,113].

Another potential method to reduce SAMs from food and feed products is to use adsorbent materials to soak up and remove the toxins. Many materials have shown the capacity to adsorb mycotoxins in vitro, thus the use of adsorbents in livestock diet as feed additives can potentially decrease the bioavailability of mycotoxins to humans and animals. As feed additives, cholestyramine, nanosilicate clay platelets, and refined calcium montmorillonite clay all reduced $\mathrm{FB}_{1}$ toxicosis [114-116]. Moreover, natural products such as the phenolic compound chlorophorin, honey, and cinnamon oil have all shown promise as fumonisin-reducing agents [117-119].

\section{Programmed Cell Death and Sphingolipids}

Almost all cells die eventually. There are four main types of cell death: necroptosis, pyroptosis, ferroptosis, and apoptosis, classified based on their distinct molecular and cellular processes and different outcomes. Apoptosis or programmed cell death (PCD) is a kind of cell suicide that strictly regulates cells that are no longer needed or are a threat to the wellbeing of multicellular organisms. Both plants and animals have PCD and they are functionally analogous to each other [120-123]. PCD plays essential roles to maintain normal physiological activities in multicellular organisms such as plants and animals and is an active self-regulating process to selectively eliminate redundant, aged, and damaged cells. PCD can be predicted for specific cells at defined developmental stages. However, PCD can also be induced by membrane-bound and cytosolic proteins stimulated by stress-induced signals. Such signals can trigger cell death via intricate cascades of transcriptional changes and post-translational protein modifications [122,124]. The characteristics of PCD include reduced cell volume, chromatin marginalization and condensation, nuclear lamina disassembly, DNA fragmentation, and apoptotic body formation, etc. [1].

PCD triggers and propagation involve many factors, including the expressions of certain cell surface receptors, transmembrane domains of several membrane proteins, intracellular proteins related to the propagation of death signals, secondary messengers including inositol triphosphate and ceramides, calcium $\left(\mathrm{Ca}^{2+}\right)$ fluxes, reactive oxygen species (ROS), regulatory factors of cell cycle, and other suppressors or activators proteins. Many of these subcellular components, genes, and signal transduction pathways involved in PCD are functionally conserved across all domains of cellular organisms, from bacteria to fungi to plants and animals. However, there are differences in the actual mechanisms among organisms, as summarized in References $[125,126]$.

Sphingolipids have been implicated to play an important role in cell growth, development, response to external environment, and PCD. As the main component of the cell membrane system, sphingolipids help to maintain the structural stability and transport of molecules across cell membranes $[127,128]$. In mammals, sphingolipids are especially abundant in the nervous system cells, with important functions in cell contact, growth, differentiation, communication, response to stress signals, and apoptosis $[30,129]$. In plants, sphingolipids are involved in response to both biotic and abiotic stresses, such as to pathogen infection, drought, and low temperature [31,130,131]. Indeed, the linkage of ceramide signaling to apoptosis has been widely reported in both plants and animals. Consequently, actions by SAMs to disrupt the functions of sphingolipids could have significant negative consequences. However, our knowledge about the roles of sphingolipids on apoptosis have also led to increasing interests on potential novel therapies using sphingolipids as treatment targets against degenerative and proliferative diseases in humans and animals, such as cancer and Parkinson's disease [132,133]. 
A large number of studies have shown that sphingolipids could serve as critical secondary messengers in signal transduction to regulate PCD [134,135]. For example, in neutrophils, sphingolipids have been linked to increased superoxide formation and $\mathrm{Ca}^{2+}$ influx, which are universal signaling molecules involved in many cellular functions [136]. The induction of PCD in Arabidopsis by ceramides was also verified to be partly dependent on ROS in mitochondria or regulated by the release of $\mathrm{Ca}^{2+}[137,138]$. In addition, increase of sphingosine level can activate the mitogen-activated protein kinase (MAPK) pathway in which MPK6 participates, promote the accumulation of sialic acid (SA), and then induce PCD [43]. Lachaud et al. found that the activated calcium-dependent kinase (CPK3) can regulate the process of sphingosine-induced PCD by dissociating CPK3 from the 14-3-3 protein-complex under increased calcium concentration induced by sphingosine. The activated CPK3 is then degraded followed by PCD induction [139].

Mutational studies of Arabidopsis and in vitro experiments have shown that ceramides, and free sphingoid bases such as sphingosine, sphinganine, and phytosphingosine, can all induce PCD. In contrast, phosphorylated products of these compounds can inhibit or alleviate PCD in plants $[44,138,140-142]$. However, phosphorylated sphingosine can inhibit the growth of yeast cells, which suggests that there are different mechanisms of action between plants and yeasts [143]. It is worth mentioning that not all ceramides can induce PCD. Nagano et al. found that when the C2 position of fatty acid in the side chain of ceramides was hydroxylated, PCD was inhibited rather than induced [144]. These results indicate that the occurrence of PCD in plants depends not only on the absolute content of sphingolipids, but also the relative ratios of various modified forms. In the next section, we will describe how SAMs are involved in PCD.

\section{SAMs Trigger PCD through Ceramide-Based Signaling Pathways}

In plants, pathogen invasions can lead to disruptions in host cellular homeostasis, and trigger cell death in susceptible varieties or even in resistant varieties with a hypersensitive response (HR). Because of its many similarities with PCD, HR is often considered as a form of PCD in plants. AAL-toxins, as the pathogenic factor of tomato stem canker disease, can induce PCD in sensitive tomato varieties resulting in fragmentation of chromosomal DNA and formation of apoptotic bodies in cells [145]. Similarly, when treated by $\mathrm{FB}_{1}$ produced by pathogenic Fusarium, Arabidopsis protoplasts showed symptoms similar to PCD in animal cells [146]. At the tissue and organ levels, Arabidopsis leaves treated with the $\mathrm{FB}_{1}$ toxin showed characteristic disease symptoms. Cells of the diseased leaves had overall phenotypes similar to HR, including callose accumulation, ROS production, and pathogenesis-related (PR) gene induction [147]. The damages caused by SAMs on host plants can further increase pathogen infection and colonization. Similar to those found in plants, SAMs can induce neuro-/renal-responses, heptatoxicosis, and neoplasms, as well as cell death in animals. The relationship between apoptosis and ceramide signaling has been established in both plants and animals in their response to SAMs [120]. For example, the induction of cell death in both tomato and African green monkey kidney (CV-1) cells occurred under similar toxin concentrations and time frames. For both types of cells, morphological markers characteristic of apoptosis were observed, including cells with positive terminal deoxynucleotidyl transferase end labeling (TUNEL), DNA fragmentations, and the formation of apoptotic-like bodies [145,148].

SAMs are structurally analogous to sphinganine and are thus effective inducers of PCD. The emerging mechanism of their actions is that SAMs can competitively bind to CerS in cells. Such binding leads to the accumulation of free sphingoid bases, the substrates of CerS, while ceramides as products of CerS were consumed and reduced, activating PCD in plant and animal cell lines $[3,85]$. For example, it was reported that $\mathrm{FB}_{1}$ is a potent competitive inhibitor of CerS from liver and brain microsomes in several mammalian cell lines $[149,150]$. An increase in sphinganine was observed in an in vivo test of CerS inhibition, as well as in FB-fed animals treated at high concentrations [2]. In addition, $\mathrm{TA}$ and $\mathrm{FB}_{1}$ can inhibit CerS in rat hepatocytes and green tomato fruits $[150,151]$. Furthermore, it was found that $\mathrm{FB}_{1}$ not only induced apoptosis in animal cells, but also altered cell morphology, cell-cell 
interactions, cell surface proteins behavior, protein kinase activity, and cell growth and viability in non-apoptotic cells [148,152]. In plant cells, after exposure to SAMs, sphingosine concentration increased significantly within a short time, followed by the accumulation of ROS in the cytoplasm and then apoptosis. These results suggested that the accumulation of sphingosine in cells was the upstream signal of ROS for cell death $[43,44,85]$. The induction of PCD by FB 1 is also related to the accumulation of ceramides. In $A$. thaliana, there are two types of CerSs that use different substrates. Class I CerSs use sphinganine and C-16 fatty acyl-CoA as substrates, while class II use phytosphingosine and very long-chain fatty acyl-CoA as substrates. $\mathrm{FB}_{1}$ mainly inhibits the activity of class II CerSs. When treated with $\mathrm{FB}_{1}$, phytosphingosine in cells increases significantly. At the same time, as the product of a previous step, sphinganine also increases, which provides more substrates for class I CerS. Consequently, the products of class I CerS in cells increase, leading to induced PCD [153,154].

\section{Plant Resistance to SAMs}

Phytohormones are also involved in the defense reaction induced by SAMs. Changes in ethylene (ET) were first discovered in AAL-induced necrosis of tomato [155]. Alteration in ethylene perception in "never ripe" mutants of tomatoes can markedly alleviate the tissue damage caused by SAMs, which indicated an ethylene-associated signal transduction during plant cell death [156]. Later, a transcription analysis of AAL-toxin-induced cell death was carried out in Arabidopsis. Genes responsive to ROS and ET were among the earliest upregulated genes [157]. Mase used VIGS (virus-induced gene silencing) analyses and verified that the ET signaling pathway and MAPK cascades were required for AAL-toxin-induced PCD in tobacco [158]. By SA-mediated ET suppression, glutathione (GSH) may be involved in resistance primarily against AAL-toxin-induced stress in Arabidopsis [159].

Unlike ethylene in host basal defense responses against the tomato pathotype of A. alternata, the jasmonate (JA)-dependent signaling pathway is not involved in host defense against the toxigenic A. alternata pathogen. JA affects pathogen acceptability via a toxin-independent mannerin in the interactions between plants and toxigenic necrotrophic fungal pathogens. It may act upstream of ethylene biosynthesis in AAL-toxin-triggered tomato cell death $[160,161]$. Later, a comparative proteomics analysis revealed that the COI1 (coronatine insensitive 1, JA receptor)-dependent JA pathway enhances AAL-toxin-induced PCD of tomato through regulating the redox status of the leaves, other phytohormone pathways, and/or important PCD components [162].

The sensitivity of tomato plants to the fungal pathogen A. alternata $\mathrm{f}$. sp. lycopersici is controlled by the Alternaria stem canker resistance locus (Asc-locus) on chromosome 3 [163]. Mutations of tomato Asc locus gives resistance to the pathogen, while overexpression of the tomato Asc-1 gene mediates high insensitivity to SAMs in tomato and confers resistance to pathogen infection in sensitive Nicotiana plants $[164,165]$. Asc-1 is a homolog of the yeast longevity assurance gene LAG1, which encodes components of sphinganine $\mathrm{N}$-acyltransferase. This resistance gene could prevent the disruption of sphingolipid metabolism during AAL-toxin-induced PCD. Both Nicotiana and Lycopersicon genera belong to Solanaceae. In tomato, insensitivity to SAMs and susceptibility to the pathogen is determined by Asc-1 [166]. In contrast, the SAM-sensitive species in the Nicotiana (except for N. umbratica) still have Asc-1 homologs and are resistant to A. alternata f. sp. lycopersici infection with HR, which indicates an additional (non-host) resistance mechanism between Nicotiana and this pathogen [167]. The multilayered defense systems also exist in Arabidopsis non-host resistance to A. alternata [168]. Similarly, although many Fusarium species produce fumonisin, they cannot infect AAL-sensitive tomato. This non-host resistance includes a multi-layer defense system involving both pre- and post-invasion, and help plants defend against various pathogens [169]. In addition, Zélicourt demonstrated that two of three Lag1 homologs in the Orobanche cumana genome were responsible for an enhanced sensitivity to AAL-toxin [170].

Aside from the above-mentioned genes, several other genes were identified from Arabidopsis and found to be involved in the AAL-induced PCD pathway, including Zinc A. thaliana 11 (a zinc finger protein ZAT11), fbr41 ( $\mathrm{FB}_{1}$ Resistant41), and baculovirus p35 gene (inhibitor of a class of cysteine 
proteases). All of them showed protective effects on AAL-toxin-induced cell death and pathogen infection in plants [171-173]. Discovery of resistant genes has provided a potential strategy for SAMs' control in crop production by plant transgenic modification.

Because of the high toxicity of fuminisins, especially $\mathrm{FB}_{1}$, a large number of studies have focused on them. So far, the mechanism of $\mathrm{FB}_{1}$ toxicity has been centered around its structural resemblance with sphinganine and consequent competitive inhibition of CerS and the disruption of lipidomic profiles. However, there is emerging evidence suggesting that $\mathrm{FB}_{1}$ can disrupt mitochondrial function and generate excessive toxic ROS.

Table 2 shows a list of reviews summarizing the latest advances related to fumonisins, in their assessment, biosynthesis, detection, crop breeding of resistant varieties, and toxicity.

Table 2. Topical reviews on fumonisins over the last five years.

\begin{tabular}{|c|c|c|}
\hline Subject & Content & Reference \\
\hline Assessment & $\begin{array}{l}\text { Biomarkers, metabolism, and biomonitoring of } \\
\text { fumonisins in human biological fluids }\end{array}$ & [174] \\
\hline Assessment & $\begin{array}{c}\text { Impact on agriculture, food, and human health and } \\
\text { their management strategies }\end{array}$ & [16] \\
\hline Assessment & $\begin{array}{l}\text { Risk assessment and intervention models for } \\
\text { fumonisin of maize in South Africa }\end{array}$ & [175] \\
\hline Assessment & $\begin{array}{l}\text { Fumonisins and related Fusarium occurrence in } \\
\text { wheat and its by-products }\end{array}$ & [176] \\
\hline Assessment & Fumonisins and their modified forms & [177] \\
\hline Assessment & $\begin{array}{l}\text { Biological methods for fumonisins reduction and } \\
\text { related Fusarium species control }\end{array}$ & [178] \\
\hline Assessment & $\begin{array}{l}\text { Fumonisins and A. alternata f. sp. Lycopersici (AAL) } \\
\text { toxins in ruminants and their forages }\end{array}$ & [19] \\
\hline Biosynthesis & $\begin{array}{l}\text { Genetic regulation of fumonisins biosynthesis by } \\
\text { specific genes and global regulators }\end{array}$ & [179] \\
\hline Biosynthesis & $\begin{array}{l}\text { Impact of environmental variables and genetics of } \\
\text { maize resistance on fumonisin accumulation }\end{array}$ & [180] \\
\hline Detection & $\begin{array}{l}\text { Analytical methods for fumonisins detection in } \\
\text { single corn kernels }\end{array}$ & [181] \\
\hline Detection & $\begin{array}{l}\text { Molecular methods for early detection of } \\
\text { fumonisin-producing } F \text {. verticillioides }\end{array}$ & [182] \\
\hline Plant resistant & $\begin{array}{l}\text { Genomic, genes, and pathways in maize resistance to } \\
\text { Fusarium ear rot and fumonisin accumulation }\end{array}$ & [183] \\
\hline Plant resistant & $\begin{array}{l}\text { Relationship between Bt maize hybrids and } \\
\text { fumonisins contamination level }\end{array}$ & [184] \\
\hline Toxicity & Mitochondrial toxicity induced by $\mathrm{FB}_{1}$ & [185] \\
\hline Toxicity & $\begin{array}{l}\text { Molecular mechanisms underlying } \mathrm{FB}_{1} \text {-mediated } \\
\text { toxicities and related interventions }\end{array}$ & [186] \\
\hline Toxicity & $\begin{array}{l}\text { CerS inhibition by fumonisins result in animal and } \\
\text { plant disease }\end{array}$ & [187] \\
\hline Toxicity & $\begin{array}{c}\text { Dietary fumonisin and growth impairment in } \\
\text { children and animals }\end{array}$ & [188] \\
\hline Toxicity & $\begin{array}{l}\text { Impact of fumonisin-contaminated feed on pig } \\
\text { intestinal health }\end{array}$ & [189] \\
\hline Toxicity & $\begin{array}{l}\text { Oxidative stress-mediated toxicity and metabolism } \\
\text { in vivo and in vitro }\end{array}$ & [190] \\
\hline
\end{tabular}

\section{Genes Responsible for SAMs Production}

In fungi, genes directly involved in the biosynthesis pathway of the same secondary metabolite are usually located at adjacent positions in gene clusters in the genome [191]. These genes are often co-expressed and co-regulated. The genes involved in fumonisin biosynthesis fit this general pattern. Specifically, Fusarium species capable of producing fumonisins typically contain one gene cluster involved in their synthesis, called the FUM gene cluster. At present, a total of 21 genes have 
been identified in FUM gene clusters of various species and verified to be involved in fumonisin biosynthesis and regulation or self-protection using a variety of approaches, such as gene knockouts, domain swapping, and heterologous expression (Table 4) [192-197]. In F. verticillioides, the FUM cluster responsible for fumonisin B biosynthesis includes 17 genes [193,197,198].

As described previously, SAMs are polyketide-derived compounds with structural similarity to sphinganine. Polyketides are synthesized by polyketide synthases (PKSs), which are large multifunctional enzymes. FUM1 is a PKS gene previously designated as FUM5 [199]. PKS encoded by FUM1 catalyzes the synthesis of an octadecanoic acid precursor as the initial step for FB biosynthesis in Fusarium spp. [200,201]. The proposed biosynthetic pathway of FB is described in Figure 4 [197]. The precursor mentioned above undergoes condensation with L-alanine to synthesize the polyketide backbone, this reaction was catalyzed by the aminotransferase Fum8 $[192,201]$. In F. oxysporum strain O-1890, the orthologue of FUM8 determines that Fusarium produces predominantly FCs [195]. The fum8 deletion in some stains of $A$. welwitschiae is also considered to be associated with the loss of $\mathrm{FB}_{2}$ production [202].

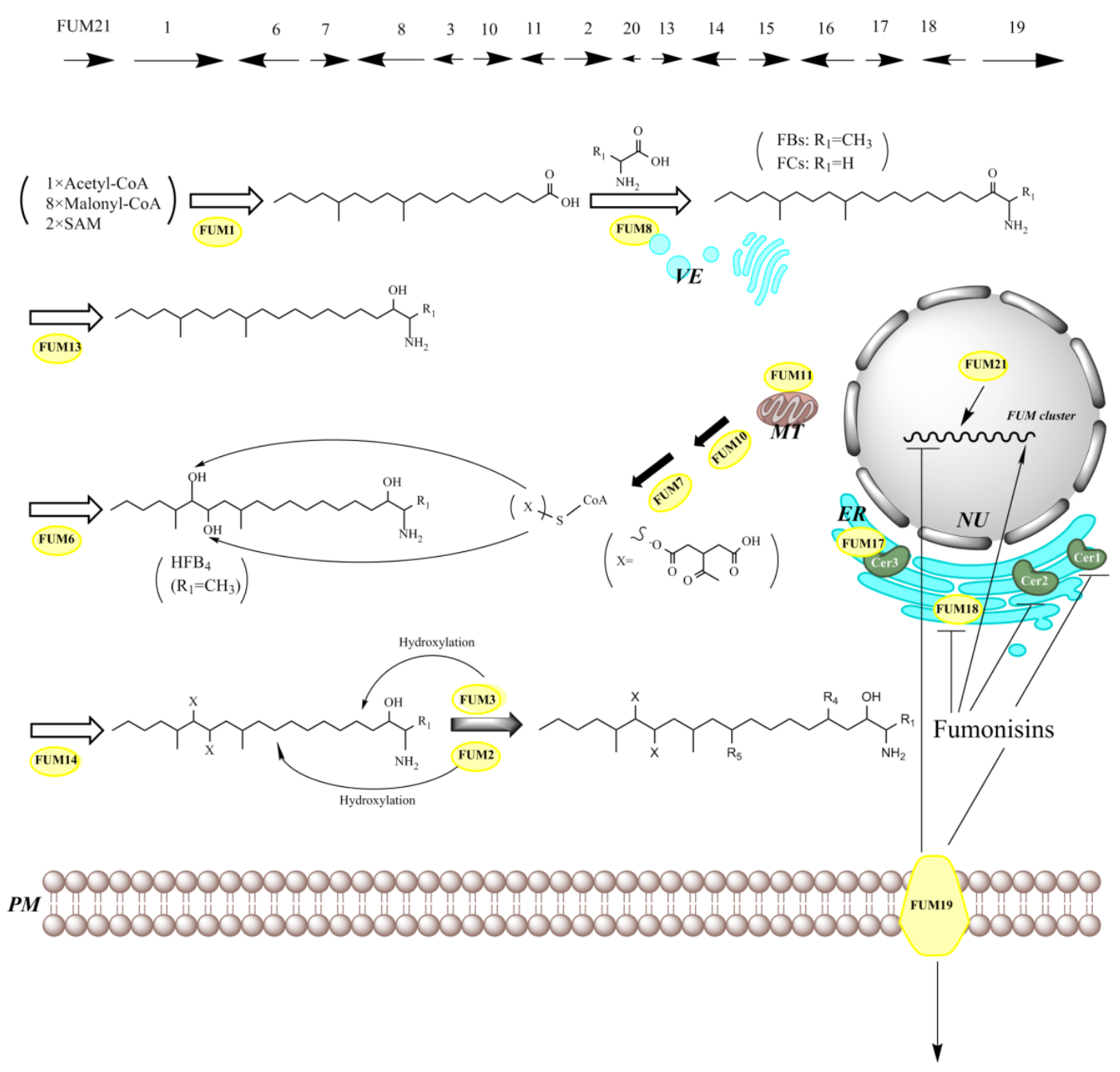

Figure 4. The FUM gene cluster, the proposed pathway of fumonisin biosynthesis, and the proposed mechanism for self-protection against fumonisins toxicity by the toxin-producing fungi (FBs and FCs). SAM, S-adenosyl methionine; VE, vesicles; MT, mitochondrion; ER, endoplasmic reticulum; NU, nucleus; PM, plasma membrane.

A likely mitochondrial carrier protein encoded by FUM11 transport the substrate tricarboxylate for Fum7 (dehydrogenase) and Fum10 (acyl-CoA synthase) to produce CoA-activated 
tricarballylic acid, which are attached to the polyketide backbone by Fum14 (condensation-domain protein) [192,194]. The ensuring steps of fumonisin biosynthesis involving various modifications of the backbone (including primarily hydroxylation) were catalyzed by several enzymes, such as Fum6/Fum12/Fum15 (cytochrome P450 monooxygenase), Fum2 (hydroxylase of C10), Fum13 (short-chain dehydrogenase/3-ketoreduction), and finally, Fum3 (hydroxylase of C5, dioxygenase), catalyzed by FUM9-encoded protein (alleles of FUM3) [192,193,203-206].

In addition, FUM21 encoding a GAL4-like Zn(II)2Cys6 transcription factor was verified to be involved in the regulation of fumonisin synthesis. However, it seemed that the deletion of FUM16 had no apparent effect on fumonisin production in F. verticillioides [194,198,207-209]. Recently, FUM17-FUM19 in F. verticillioides were found to help the fungus to avoid its own toxicity during fumonisin production. Fum19 is an ATP-binding cassette transporter (ABC transporter) and acts as a repressor of the FUM gene cluster. FUM17 and FUM18 are CerS homologs. FUM18 could fully complement the yeast CerS null mutant $L A G 1 / L A C 1$, while co-expression of FUM17 and CER3 partially complemented. Both the Fum17 and Fum18 proteins enable F. verticillioides to increase its resistance of fumonisin by providing FUM cluster-encoded CerS activity as a first level of self-protection [197].

Aside from the FUM genes, other genes like FST1 (transporter), FUG1 (transcription or signal transduction factors), CPP1 (protein phosphatase type 2A catalytic subunit), and FvVEl (regulator) in F. verticillioides, PKS3 and PKS11 in F. proliferatum, and GATA-type transcription factors AreA and AreB (known as the global nitrogen regulators) in F. fujikuroi have also been demonstrated to have an important role in fumonisin biosynthesis and regulation [209-214]. In addition, a degenerated, over-represented motif which is potentially involved in the cis-regulation of FUM genes and fumonisin biosynthesis was also identified from both F. verticillioides and Asp. niger, while it was not found in fumonisins non-producing fungi containing various FUM homologues [215].

Several abiotic and biotic factors have been found to affect the expression of FUM genes and regulate biosynthesis of fumonisin. These factors include water activity, temperature, carbon sources and other nutrients, host plant species and varieties or their extracts, and plant age [216-220]. Mature plants and extracts from those plants are often associated with higher concentrations of SAMs. It has been suggested that harvesting the crop at earlier stages other than full maturity could be one of the strategies to control fumonisin contamination [221,222].

The genome sequencing and analysis of Asp. niger revealed that its genome contained a gene cluster (fum cluster) homologous to the FUM cluster in Fusarium species (shown in Table 4). Specifically, 12 homologues of the fumonisin synthesis genes were found, including fum1, fum3, fum6, fum7, fum8, fum10, fum13 to fum16, fum19, and fum 21 genes [208,223,224]. This gene cluster is also found in fumonisin-producing isolates of Asp. welwitschiae but is absent from the genomes of other sequenced Aspergilli that do not produce fumonisin, such as Asp. fumigatus, Asp. oryzae, and Asp. nidulans [7,208]. In addition, homologs of multiple fum genes have been found in several other Aspergilli spp. but where no fumonisin production has been detected (summarized in Table 3). Some of the Aspergullus spp. contain genes that are unique to them. For example, a dehydrogenase gene ( $s d r 1)$ of a short-chain length was found in the fum cluster of Asp. niger but is absent in the FUM gene cluster of Fusarium spp. In contrast, the Fusarium FUM2 gene with a function of hydroxylation at the $\mathrm{C}-10$ backbone position of fumonisin is absent in the Asp. niger fum cluster [207,208]. This result is consistent with the study that shows that Asp. niger only produces fumonisins $\mathrm{FB}_{2}, \mathrm{FB}_{4}$, and $\mathrm{FB}_{6}$, which lack a hydroxyl at $\mathrm{C}-10[7,225,226]$. However, isolates of several black aspergilli (including A. niger, Asp. foetidus, and $A$. tubingensis) isolated from peanuts and maize also produced $\mathrm{FB}_{1}$ and $\mathrm{FB}_{3}$, consistent with a complex biosynthesis pattern of the fumonisins in Aspergilli spp. [227]. 
Table 3. Difference in genomic context of fumonisin biosynthetic gene (fum) cluster between strains of Aspergillus spp.

\begin{tabular}{cccc}
\hline Fungi & \multicolumn{1}{c}{ Stains } & fum Cluster & Reference \\
\hline \multirow{2}{*}{ Asp. niger } & fumonisin-producing strains & fum cluster & {$[208]$} \\
\cline { 2 - 4 } Asp. welwitschiae & fumonisin-non-producing strains & Intact fum cluster & {$[7,235]$} \\
\cline { 2 - 4 } & fumonisin-producing strains & fum cluster & {$[7]$} \\
\hline \multirow{2}{*}{ Asp. tubingensis } & fumonisin-non-producing strains & $\begin{array}{c}\text { Three fum cluster types } \\
\text { including an intact cluster }\end{array}$ & {$[7,235]$} \\
\cline { 2 - 4 } & fumonisin-non-producing strains & $\begin{array}{c}\text { Multiple patterns of } \\
\text { fum gene deletion }\end{array}$ & {$[$ [7] } \\
\hline Asp. brasiliensis & fumonisin-non-producing strains & $\begin{array}{c}\text { Multiple patterns of } \\
\text { fum gene deletion }\end{array}$ & [7] \\
\hline Asp. luchuensis & fumonisin-non-producing strains & $\begin{array}{c}\text { Multiple patterns of } \\
\text { fum gene deletion }\end{array}$ & {$[7,236]$} \\
\hline Asp. fumigatus & fumonisin-non-producing strains & Not detected & {$[208]$} \\
\hline Asp. oryzae & fumonisin-non-producing strains & Not detected & {$[208]$} \\
\hline Asp. nidulans & fumonisin-non-producing strains & Not detected & {$[208]$} \\
\hline Asp. foetidus & fumonisin-producing strains & Not tested & {$[227]$} \\
\hline
\end{tabular}


Table 4. Homologous genes and their functional roles in the biosynthesis of SAMs.

\begin{tabular}{|c|c|c|c|c|}
\hline \multicolumn{3}{|c|}{ Homologue of Cluster Genes } & \multirow[t]{2}{*}{ Predict Gene Product and Function } & \multirow[t]{2}{*}{ Reference } \\
\hline fumonisin & & AAL-toxin & & \\
\hline Fusarium spp. & Aspergillus spp. & A. alternata & & {$[169,224]$} \\
\hline $\begin{array}{c}\text { FUM1 } \\
\text { (fumonisin biosynthetic gene 1, } \\
\text { previously designated as FUM5)) }\end{array}$ & fum1 & $\begin{array}{c}A L T 1 \\
\text { (AAL-toxin biosynthetic } \\
\text { gene 1) }\end{array}$ & polyketide synthase & {$[12,199,200]$} \\
\hline FUM2 & absent & & Dioxygenase for hydroxylation of $\mathrm{C} 10$ & [228] \\
\hline FUM3 & fum3 & & Dioxygenase for hydroxylation of C5 (the same gene as FUM9) & {$[205,228,229]$} \\
\hline FUM4 & & & Not clear & {$[230]$} \\
\hline FUM6 & fum6 & $A L T 2$ & $\begin{array}{c}\text { Cytochrome P450 monooxygenase-reductase fusion proteins for } \\
\text { hydroxylation of C14/C15 }\end{array}$ & {$[192,231]$} \\
\hline FUM7 & fum7 & ALT3 & $\begin{array}{l}\text { Type III alcohol dehydrogenases for PTCA } \\
\text { (propane-1,2,3-tricarboxylic acid) side chain formation }\end{array}$ & {$[192,194,232$} \\
\hline FUM8 & fum8 & & $\begin{array}{l}\alpha \text {-oxoamine synthase and homologous for amino transfer and } \\
\text { FBs/FCs production }\end{array}$ & {$[192,195]$} \\
\hline FUM10 & fum10 & & Fatty acyl-CoA synthase for PTCA esterification & {$[193,194]$} \\
\hline FUM11 & & & mitochondrial transport protein for PTCA transport & {$[193,194]$} \\
\hline FUM12 & & & cytochrome P450 monooxygenases & [193] \\
\hline FUM13 & fum13 & ALT6 & Short-chain dehydrogenase/ketoreductase of C3 & {$[193,204,206$} \\
\hline FUM14 & fum14 & & Non-ribosomal peptide synthetase for PTCA esterification & {$[193,194,233$} \\
\hline FUM15 & fum15 & & Cytochrome P450 monooxygenases & [193] \\
\hline FUM16 & fum16 & & Fatty acyl-CoA synthetase & {$[193,194,224$} \\
\hline FUM17 & & & CerS for self-protection against fumonisins & {$[193,197]$} \\
\hline FUM18 & & & CerS for self-protection against fumonisins & {$[193,197]$} \\
\hline FUM19 & fum19 & & $\mathrm{ABC}$ transport protein as a repressor of FUM gene cluster & {$[193,197]$} \\
\hline FUM20 & & & Not clear & [234] \\
\hline FUM21 & fum 21 & ALT13 & $\mathrm{Zn}(\mathrm{II}) 2 \mathrm{Cys} 6$ transcription factor & [198] \\
\hline absent & SDR1 & & Short-chain dehydrogenase/reductase (SDR) & [7] \\
\hline
\end{tabular}


AAL-toxins are produced by A. alternata f. sp. Lycopersici, a specific pathotype of a common plant fungal pathogen in a genus different from Aspergillus and Fusarium. This pathotype can produce polyketide-derived compounds similar in structure to fumonisins produced by Fusarium species. The ALT (AAL-toxins synthesis) genes are also located as a cluster on a conditional disposable (CD) chromosome of $\sim 1.0 \mathrm{Mb}$ in all strains of the tomato pathotype of $A$. alternata from different countries [237]. Such CD chromosomes carrying a toxin biosynthesis gene cluster were also found in other pathotypes of A. alternata [169]. They control other HSTs production and pathogenicity to their host. They could maintain stably in a new genetic background to an expanded range of pathogenicity, which was verified by a protoplast fusion test [238]. The AAL-toxin gene cluster includes at least 13 genes in a $120 \mathrm{~kb}$ region, some of which showed significant similarity to the FUM gene cluster consisting of 17 genes in a $45.5 \mathrm{~kb}$ region. However, the arrangement of genes in the ALT and FUM clusters differs between these two groups of fungi. In addition, in one strain, As-27 of A. alternata, there were two sets of the AAL-toxin biosynthetic gene cluster on the CD chromosome [169]. The synthesis of AAL-toxins was found to be initiated by ALT1-encoded PKSs to produce the aminopentol backbone, which was then modified by other enzymes [239]. The functional similarity between ALT1 and FUM1 was confirmed when fumonisin biosynthesis in FUM1-disrupted $F$. verticillioides was restored when complemented by the ALT1 from A. alternata [240]. Similarly, expression of ALT1 and production of AAL-toxins were also found to be regulated by the global regulator LaeA [241]. AAL-toxin accumulation also benefits from high water activity $(0.995 \mathrm{aw})$ and high temperature (above $30^{\circ} \mathrm{C}$ ) during the incubation period of the pathogen [242].

Interestingly, a PKS gene similar to FUM1 and orthologs of the FUM gene cluster were found in the genome of Cochliobolus spp. by phylogenetic analysis of fungal polyketide. These fungi were also speculated to produce a fumonisin or other SAMs $[243,244]$. To predict the potential distribution of SAM production in fungi, Kim et al. proposed a hypothesis on SAM biosynthetic gene clusters based on fumonisin biosynthesis model. This putative gene cluster should include a PKS, an aminotransferase, and a dehydrogenase gene. Their model showed that sixty-nine species of the Fusarium genus and species of twenty-four other fungal genera were predicted to have at least one SAM cluster [245].

\section{Evolution of SAMs Production}

Horizontal gene transfer (HGT) has been proposed as a major mechanism responsible for the acquisition and evolution of fumonisins and AAL-toxins biosynthetic gene clusters among divergent fungi $[7,9,169,224]$. In Fusarium, genome sequence analyses revealed that the fumonisin biosynthetic genes (FUM) are clustered and show a consistent gene organization among most species. For example, the FUM clusters in F. oxysporum, F. proliferatum, and F. verticillioides exhibit relatively little variability, with the order and orientation of genes within the clusters all being the same as each other. In addition, their sequence variability among the orthologues of coding regions from F. oxysporum and F. verticillioides is relatively low $[193,195]$. The two different species of Aspergillus that produce fumonisins, Asp. niger and Asp. welwitschiae, are also similar to each other in their gene order but different from that of the FUM cluster in Fusarium [224]. At present, the tomato pathotype of A. alternata was the only species of genus Alternaria capable of producing SAMs and this pathotype has clustered genes (involved in AAL-toxin biosynthesis) similar to the FUM cluster in Fusarium $[169,237]$. Together, the gene structure and sequence analyses suggested that the SAMs biosynthetic gene cluster likely originated in Fusarium and transferred to Asp. niger and A. alternata by HGT. The similarities in chemical structure and cytotoxicity on plants and animals between fumonisins and AAL-toxins are also supportive of this hypothesis. However, the differences between FUM clusters and the AAL-toxins biosynthetic gene cluster also suggested that there has been significant divergence between them.

Analyses of the FUM gene cluster among Fusarium species also revealed evidence for gene gain, loss, and mutations of different genes. For example, not all Fusarium species can produce fumonisins. Even for species that can synthesize fumonisins, some strains produce more than others under the same experimental conditions, while other strains do not produce the toxins at all $[9,196]$. Indeed, for certain 
strains, while the FUM genes were detected, there was no detectable fumonisin. This was likely due to the accumulation of mutations leading to the FUM genes being nonfunctional. For example, several mutations have been found in FUM7 and FUM21 in F. fujikuroi [246]. Furthermore, several fumonisin-non-producing Fusarium species lack the fumonisin biosynthetic genes but retain homologs of several genes that flank the Fum cluster in F. verticillioides [247]. Interestingly, the flanking regions of the FUM cluster often differ between species, consistent with the independent origins of the FUM cluster, including independent acquisition and/or loss of the gene cluster by fumonisin-producing species [195]. For example, fumonisin-non-producing strains of $F$. verticillioides isolated from banana did not contain the functional fumonisin biosynthetic gene (FUM) cluster but did contain portions of FUM21 and FUM19 flanking the cluster, both of which are the terminal genes at each end of the FUM cluster. However, the banana strains are still pathogenic to banana, but they do not show the same pathology as the fumonisin-producing strains do on maize. When a banana strain was co-transformed with two overlapping cosmids containing the entire FUM gene cluster, fumonisin production and pathogenicity on maize seedlings were recovered [248]. Similar to Fusarium, FB-non-producing isolates of Asp. niger or other Aspergillus species also had an intact fum cluster or multiple patterns of fum gene deletion, respectively (shown in Table 3). Similarly, the AAL-toxin-production gene cluster in A. alternata was likely derived from Fusarium species by an HGT event. Evidence from the ALT gene cluster distributed in isolates of A. alternata also supports this hypothesis of HGTs within AAL-toxin-producing pathogens [237]. Together, these results suggest that there have been multiple HGTs of the cluster between species, as well as duplication and loss of the whole or part of the cluster after acquisition [9].

The hypothesis that multiple HGTs were involved in generating the current distribution of FUM gene clusters is further supported by phylogenetic studies. Specifically, phylogenetic trees based on genes from the FUM cluster often do not parallel that of the Fusarium species tree based on other genes [9]. In Fusarium, the translation elongation factor (tef- $1 \alpha$ ) gene is the most commonly used marker gene for taxonomic studies. However, sequences of the tef- $1 \alpha$ are often insufficient for distinguishing fumonisin-producing isolates from different countries and/or host plants. In contrast, DNA sequence polymorphisms based on FUM1 often provide better resolutions among pathotypes [196,249-253]. For example, phylogenetic analysis of $38 \mathrm{~F}$. proliferatum isolates originating from different hosts showed that sequence variation among strains in the FUM1 gene was correlated with that of the host plants. Specifically, phylogenetic analysis based on the partial FUM1 sequences differentiated the host-related groups more clearly than that based on tef- $1 \alpha$ sequences. The best distinguished group consists of garlic-derived isolates and formed a separate branch on a FUM1-based dendrogram [196,254]. Similarly, FUM1 sequence divergence analysis on F. proliferatum and F. verticillioides strains isolated from pea also formed a distinct group when compared to strains derived from different host species [253].

Aside from gene differences among isolates from different host plants, variations of both toxigenic potential and growth patterns may also differ between isolates derived from the same host plants. While no difference was observed in FB levels measured among pea seeds, the FB productions differed between selected strains of F. proliferatum in rice cultures [253]. Among all these test isolates of F. proliferatum, the most varied group of isolates found so far were those isolated from maize [196,254]. Both the inter- and intra-specific variation in FBs synthesis level can at least partly be explained by the sequence differences inside the FUM cluster.

In summary, the analyses so far suggested that the FUM gene cluster was responsible for fumonisin biosynthesis. Mutation and deletion of some or all of the genes in the cluster could result in limited or no production of fumonisin, leading to a weaker disease development of the pathogen on the host plant. Sequence analyses showed that A. alternata has likely gained the ability for AAL-toxin production due to HGT of the SAMs gene cluster from fumonisin-producing Fusarium species followed by independent evolution in pathogen-host interaction. The divergent patterns of toxin biosynthesis gene sequence divergence may explain the differences between fumonisins and AAL-toxins in both their productions and their impacts on host-pathogen interactions. 


\section{Detection Method of SAMs}

A variety of methods have been developed to detect SAMs, including HPLC with fluorescence/evaporative light scattering detection or mass spectrometry (MS), thin-layer chromatography (TLC), ELISA, Fourier transform near infrared (FT-NIR) spectroscopy, and so on [255-263]. While these traditional analytical methods were designed to detect and quantify known compounds for which standards are available, there is clear evidence that many unknown derivatives may exist in food and food products and some of these could be toxic to animals, including humans [39]. In 2015, a semi-targeted method combining product ion filtering and rapid polarity switching was designed for fast detection of all known fumonisins and AAL-toxins. Some new structurally related emerging toxins were also discovered by this method [26].

Aside from method development that targets potentially novel SAMs not reported before, there are also developments for efficient methods that target the detection of known SAMs. Indeed, several new methods based on immunoassay were developed for simple, rapid, and ultrasensitive on-site quantification of SAMs. For example, one method used chemiluminescent biosensors integrating a competitive lateral flow immunoassay and a charge-coupled device camera to detect FBs [264,265]. Another method uses gold nanoparticles or quantum dots nanobeads based on monoclonal antibodies against fumonisin and allows rapid detection of this mycotoxin in one step [266-268]. Furthermore, a loop-mediated isothermal amplification (LAMP) assay, based on the detection of fum10, could specifically detect the genes involved in $\mathrm{FB}_{2}$ biosynthesis in Aspergillus species that could be evaluated using the naked eye in a short time [269]. This method was also applied to detect $\mathrm{FB}_{1}$ targeting the FUM1 gene in Fusarium [270]. The direct detection of genes involved in the biosynthesis of SAMs in agriculture production systems allows broad evaluations of the potential fumonisin-producing strains in food and feed products. To this end, multiplex PCR has shown great promise for detection of multiple fumonisin-producing Fusarium and Aspergillus species [271-273].

While the current focuses are on the known SAMs with known toxicities, there is increasing evidence that some of these toxins are masked and not easily detected or quantified. To ensure food safety, both the free forms and the masked forms of mycotoxins should be detected and quantified. The masked mycotoxins are usually modified forms of the mycotoxins by plant enzymes during infection and are not typically detectable during routine analysis. For example, the masked mycotoxins may conjugate with polar substances, store in the vacuole in the soluble form, or bind to macromolecules, and thus change their physiological properties. While the masked mycotoxins are often less toxic than the unmasked forms, they could be easily converted to the unmasked toxin forms, including during food digestion [274,275]. The most representative masked mycotoxins are the modified forms of Zearalenone (ZEN), DON, and fumonisins [276-279]. The so-called hidden fumonisins could form non-covalent bonds with food macro-constituents such as those in starch-based products. In certain situations, the masked fumonisins may be present in food at quantities much higher than the free forms. Many factors could influence the relative portions of the SAMs in masked forms, including crop growth conditions and food storage and processing techniques [279-282]. These hidden dangers require that novel method(s) be developed to allow the detection and quantification of the masked forms of SAMs as well as other mycotoxins.

\section{Concluding Remarks}

SAMs are highly toxic fungal compounds that have attracted significant attention from broad communities. They have toxicities to both plants and animals. These SAMs-producing pathogens are widely distributed in nature and closely related to agricultural production. Since its discovery in the mid-1980s, fumonisin has been among the mycotoxins with the greatest concern. As of now, Scopus database citations of fumonisin are above 5000, including 500+ reviews. SAMs are a series of compounds with structural similarity to sphingosine. As detection methods improve, additional new analogs have been continuously discovered. Research so far has shown that the toxicity and activity of SAMs are dependent on their structures. In this review, we summarized the detoxification method 
based on their structural properties using chemical, biological, and physical strategies. The toxicity of SAMs is mostly due to their inhibitory effects on CerS, disruption on sphingolipid metabolism, and initiation on PCD. Except for the adverse effect of SAMs on animals and humans, its phytotoxicity (e.g., AAL-toxin) could potentially be used for herbicide development and a model for studying the molecular mechanism of PCD in plants. Horizontal gene transfers on the SAMs biosynthesis gene cluster seemed widespread in these toxin-producing fungi, especially among Fusarium spp. Such phylogenetic distribution patterns suggest that there are potentially other fungi capable of producing SAMs, including their various modified forms. These and other issues require continued efforts from the scientific community on SAMs.

Author Contributions: J.X. conceived the review and finalized the manuscript, J.C. conducted the literature search and drafted the manuscript, Z.L. drafted all the figures and tables, Y.C. coordinated the format and submitted the manuscript to the journal, C.G., L.G., and T.W. helped to revise the final manuscript. All authors have read and agreed to the published version of the manuscript.

Funding: This research was supported by the National Key R\&D Program of China (N0: 2018YFD0201106), Natural Science Foundation of Hunan (2020JJ5637) and Agricultural Science and Technology Innovation Program of the Chinese Academy of Agricultural Sciences (Grant CAAS-ASTIP-2015-IBFC).

Conflicts of Interest: The authors declare no conflict of interest.

\section{References}

1. Gilchrist, D.G. Programmed cell death in plant disease: The purpose and promise of cellular suicide. Annu. Rev. Phytopathol. 1998, 36, 393-414. [CrossRef]

2. Riley, R.T.; Wang, E.; Schroeder, J.J.; Smith, E.R.; Plattner, R.D.; Abbas, N.; Yoo, H.S.; Merrill, A.H., Jr. Evidence for disruption of sphingolipid metabolism as a contributing factor in the toxicity and carcinogenicity of fumonisins. Nat. Toxins 1996, 4, 3-15. [CrossRef] [PubMed]

3. Merrill, A.H., Jr.; Sullards, M.C.; Wang, E.; Voss, K.A.; Riley, R.T. Sphingolipid metabolism: Roles in signal transduction and disruption by fumonisins. Environ. Health Persp. 2001, 109, 283-289. [CrossRef]

4. Gelderblom, W.C.A.; Jaskiewicz, K.; Marasas, W.F.O.; Thiel, P.G.; Horak, R.M.; Vleggaar, R.; Kriek, N.P.J. Fumonisins-novel mycotoxins with cancer-promoting activity produced by Fusarium moniliforme. Appl. Environ. Microb. 1988, 54, 1806-1811. [CrossRef] [PubMed]

5. Rheeder, J.P.; Marasas, W.F.O.; Vismer, H.F. Production of fumonisin analogs by Fusarium species. Appl. Environ. Microb. 2002, 68, 2101-2105. [CrossRef]

6. Frisvad, J.C.; Smedsgaard, J.; Samson, R.A.; Larsen, T.O.; Thrane, U. Fumonisin B 2 production by Aspergillus niger. J. Agric. Food Chem. 2007, 55, 9727-9732. [CrossRef]

7. Susca, A.; Proctor, R.H.; Butchko, R.A.E.; Haidukowski, M.; Stea, G.; Logrieco, A.; Moretti, A. Variation in the fumonisin biosynthetic gene cluster in fumonisin-producing and nonproducing black aspergilli. Fungal Genet. Biol. 2014, 73, 39-52. [CrossRef]

8. Chen, J.; Mirocha, C.J.; Xie, W.; Hogge, L.; Olson, D. Production of the mycotoxin fumonisin $\mathrm{B}_{1}$ by Alternaria alternata f. sp. lycopersici. Appl. Environ. Microb. 1992, 58, 3928-3931. [CrossRef]

9. Proctor, R.H.; Van Hove, F.; Susca, A.; Stea, G.; Busman, M.; van der Lee, T.; Waalwijk, C.; Moretti, A.; Ward, T.J. Birth, death and horizontal transfer of the fumonisin biosynthetic gene cluster during the evolutionary diversification of Fusarium. Mol. Microbiol. 2013, 90, 290-306. [CrossRef]

10. Mogensen, J.M.; Møller, K.A.; Von Freiesleben, P.; Labuda, R.; Varga, E.; Sulyok, M.; Kubátová, A.; Thrane, U.; Andersen, B.; Nielsen, K.F. Production of fumonisins $\mathrm{B}_{2}$ and $\mathrm{B}_{4}$ in Tolypocladium species. J. Ind. Microbiol. Biot. 2011, 38, 1329-1335. [CrossRef]

11. Alabouvette, C.; Lemanceau, P.; Steinberg, C. Recent advances in the biological control of fusarium wilts. Pestic. Sci. 1993, 37, 365-373. [CrossRef]

12. Desjardins, A.E.; Plattner, R.D.; Nelsen, T.C.; Leslie, J.F. Genetic analysis of fumonisin production and virulence of Gibberella fujikuroi mating population A (Fusarium moniliforme) on maize (Zea mays) seedlings. Appl. Environ. Microb. 1995, 61, 79-86. [CrossRef] [PubMed]

13. Chulze, S.N. Strategies to reduce mycotoxin levels in maize during storage: A review. Food Addit. Contam. A 2010, 27, 651-657. [CrossRef] [PubMed] 
14. Munkvold, G.P.; McGee, D.C.; Carlton, W.M. Importance of different pathways for maize kernel infection by Fusarium moniliforme. Phytopathology 1997, 87, 209-217. [CrossRef]

15. Williams, L.D.; Glenn, A.E.; Bacon, C.W.; Smith, M.A.; Riley, R.T. Fumonisin production and bioavailability to maize seedlings grown from seeds inoculated with Fusarium verticillioides and grown in natural soils. J. Agr. Food Chem. 2006, 54, 5694-5700. [CrossRef]

16. Kamle, M.; Mahato, D.K.; Devi, S.; Lee, K.E.; Kang, S.G.; Kumar, P. Fumonisins: Impact on agriculture, food, and human health and their management strategies. Toxins 2019, 11, 328. [CrossRef]

17. Chu, F.S.; Li, G.Y. Simultaneous occurrence of fumonisin $B_{1}$ and other mycotoxins in moldy corn collected from the People's Republic of China in regions with high incidences of esophageal cancer. Appl. Environ. Microb. 1994, 60, 847-852. [CrossRef]

18. Marasas, W.F.O.; Riley, R.T.; Hendricks, K.A.; Stevens, V.L.; Sadler, T.W.; Gelineau-Van Waes, J.; Missmer, S.A.; Cabrera, J.; Torres, O.; Gelderblom, W.C.A.; et al. Fumonisins Disrupt Sphingolipid Metabolism, Folate Transport, and Neural Tube Development in Embryo Culture and In Vivo: A Potential Risk Factor for Human Neural Tube Defects among Populations Consuming Fumonisin-Contaminated Maize. J. Nutr. 2004, 134, 711-716. [CrossRef]

19. Gallo, A.; Giuberti, G.; Frisvad, J.C.; Bertuzzi, T.; Nielsen, K.F. Review on mycotoxin issues in ruminants: Occurrence in forages, effects of mycotoxin ingestion on health status and animal performance and practical strategies to counteract their negative effects. Toxins 2015, 7, 3057-3111. [CrossRef]

20. Ross, P.F.; Rice, L.G.; Osweiler, G.D.; Nelson, P.E.; Richard, J.L.; Wilson, T.M. A review and update of animal toxicoses associated with fumonisin-contaminated feeds and production of fumonisins by Fusarium isolates. Mycopathologia 1992, 117, 109-114. [CrossRef]

21. Harrison, L.R.; Colvin, B.M.; Greene, J.T.; Newman, L.E.; Cole, J.R., Jr. Pulmonary Edema and Hydrothorax in Swine Produced by Fumonisin B 1 , a Toxic Metabolite of Fusarium Moniliforme. J. Vet. Diagn. Investig. 1990, 2, 217-221. [CrossRef] [PubMed]

22. Gilchrist, D.G.; Grogan, R.G. Production and nature of a host-specific toxin from Alternaria alternata f. sp. lycopersici. Phytopathology 1976, 66, 165-171. [CrossRef]

23. Meena, M.; Samal, S. Alternaria host-specific (HSTs) toxins: An overview of chemical characterization, target sites, regulation and their toxic effects. Toxicol. Rep. 2019, 6, 745-758. [CrossRef] [PubMed]

24. Abbas, H.K.; Duke, S.O.; Paul, R.N.; Riley, R.T.; Tanaka, T. AAL-toxin, a potent natural herbicide which disrupts sphingolipid metabolism of plants. Pestic. Sci. 1995, 43, 181-187. [CrossRef]

25. Mesbah, L.A.; Van Der Weerden, G.M.; Nijkamp, H.J.J.; Hille, J. Sensitivity among species of Solanaceae to AAL toxins produced by Alternaria alternata f.sp. lycopersici. Plant Pathol. 2000, 49, 734-741. [CrossRef]

26. Renaud, J.B.; Kelman, M.J.; Qi, T.F.; Seifert, K.A.; Sumarah, M.W. Product ion filtering with rapid polarity switching for the detection of all fumonisins and AAL-toxins. Rapid Commun. Mass Sp. 2015, 29, 2131-2139. [CrossRef]

27. Abbas, H.K.; Riley, R.T. The presence and phytotoxicity of fumonisins and AAL-toxin in Alternaria alternata. Toxicon 1996, 34, 133-136. [CrossRef]

28. Yamagishi, D.; Akamatsu, H.; Otani, H.; Kodama, M. Pathological evaluation of host-specific AAL-toxins and fumonisin mycotoxins produced by Alternaria and Fusarium species. J. Gen. Plant Pathol. 2006, 72, 323-327. [CrossRef]

29. Merrill, A.H. Sphingolipid Biosynthesis. In Encyclopedia of Biological Chemistry, 2nd ed.; Lennarz, W.J., Lane, M.D., Eds.; Elsevier Inc.: Amsterdam, The Netherlands, 2013; pp. 281-286. [CrossRef]

30. Hannun, Y.A.; Obeid, L.M. Sphingolipids and their metabolism in physiology and disease. Nat. Rev. Mol. Cell Biol. 2018, 19, 175-191. [CrossRef]

31. Huby, E.; Napier, J.A.; Baillieul, F.; Michaelson, L.V.; Dhondt-Cordelier, S. Sphingolipids: Towards an integrated view of metabolism during the plant stress response. New Phytol. 2020, 225, 659-670. [CrossRef]

32. Li, Q.; Fang, H.; Dang, E.; Wang, G. The role of ceramides in skin homeostasis and inflammatory skin diseases. J. Dermatol. Sci. 2020, 97, 2-8. [CrossRef] [PubMed]

33. Bartók, T.; Szécsi, Á.; Szekeres, A.; Mesterházy, Á.; Bartók, M. Detection of new fumonisin mycotoxins and fumonisin-like compounds by reversed-phase high-performance liquid chromatography/electrospray ionization ion trap mass spectrometry. Rapid Commun. Mass Sp. 2006, 20, 2447-2462. [CrossRef] [PubMed]

34. Abbas, H.K.; Duke, S.O.; Tanaka, T. Phytotoxicity of fumonisins and related compounds. Toxin Rev. 1993, 12, 225-251. [CrossRef] 
35. Branham, B.E.; Plattner, R.D. Isolation and characterization of a new fumonisin from liquid cultures of Fusarium moniliforme. J. Nat. Prod. 1993, 56, 1630-1633. [CrossRef]

36. Seo, J.A.; Kim, J.C.; Lee, Y.W. N-acetyl derivatives of type C fumonisins produced by Fusarium oxysporum. J. Nat. Prod. 1999, 62, 355-357. [CrossRef]

37. Musser, S.M.; Gay, M.L.; Mazzola, E.P.; Plattner, R.D. Identification of a new series of fumonisins containing 3-hydroxypyridine. J. Nat. Prod. 1996, 59, 970-972. [CrossRef]

38. Abbas, H.K.; Shier, W.T.; Seo, J.A.; Lee, Y.W.; Musser, S.M. Phytotoxicity and cytotoxicity of the fumonisin C and P series of mycotoxins from Fusarium spp. fungi. Toxicon 1998, 36, 2033-2037. [CrossRef]

39. Bartók, T.; Tölgyesi, L.; Szekeres, A.; Varga, M.; Bartha, R.; Szécsi, A.; Bartók, M.; Mesterházy, A. Detection and characterization of twenty-eight isomers of fumonisin $\mathrm{B}_{1}\left(\mathrm{FB}_{1}\right)$ mycotoxin in a solid rice culture infected with Fusarium verticillioides by reversed-phase high-performance liquid chromatography/electrospray ionization time-of-flight and ion trap mass spectrometry. Rapid Commun. Mass Sp. 2010, 24, 35-42. [CrossRef]

40. Bottini, A.T.; Bowen, J.R.; Gilchrist, D.G. Phytotoxins. II. Characterization of a phytotoxic fraction from Alternaria alternata f. sp. lycopersici. Tetrahedron Lett. 1981, 22, 2723-2726. [CrossRef]

41. Bottini, A.T.; Gilchrist, D.G. Phytotoxins. I. A 1-amino dimethyl heptadecapentol from alternaria alternata f. sp. lycopersici. Tetrahedron Lett. 1981, 22, 2719-2722. [CrossRef]

42. Caldas, E.D.; Jones, A.D.; Ward, B.; Winter, C.K.; Gilchrist, D.G. Structural Characterization of Three New AAL Toxins Produced by Alternaria alternata f. sp. lycopersici. J. Agric. Food Chem. 1994, 42, 327-333. [CrossRef]

43. Saucedo-García, M.; Guevara-García, A.; González-Solís, A.; Cruz-García, F.; Vázquez-Santana, S.; Markham, J.E.; Lozano-Rosas, M.G.; Dietrich, C.R.; Ramos-Vega, M.; Cahoon, E.B.; et al. MPK6, sphinganine and the LCB2a gene from serine palmitoyltransferase are required in the signaling pathway that mediates cell death induced by long chain bases in Arabidopsis. New Phytol. 2011, 191, 943-957. [CrossRef] [PubMed]

44. Shi, L.; Bielawski, J.; Mu, J.; Dong, H.; Teng, C.; Zhang, J.; Yang, X.; Tomishige, N.; Hanada, K.; Hannun, Y.A.; et al. Involvement of sphingoid bases in mediating reactive oxygen intermediate production and programmed cell death in Arabidopsis. Cell Res. 2007, 17, 1030-1040. [CrossRef] [PubMed]

45. Spassieva, S.D.; Markham, J.E.; Hille, J. The plant disease resistance gene Asc-1 prevents disruption of sphingolipid metabolism during AAL-toxin-induced programmed cell death. Plant J. 2002, 32, 561-572. [CrossRef]

46. Kluepfel, D.; Bagli, J.; Baker, H.; Charest, M.P.; Kudelski, A.; Sehgal, S.N.; Vézina, C. Myriocin, a new antifungal antibiotic from Myriococcum albomyces. J. Antibiot. 1972, 25, 109-115. [CrossRef]

47. Šašek, V.; Sailer, M.; Vokoun, J.; Musílek, V. Production of thermozymocidin (myriocin) by the pyrenomycete Melanconis flavovirens. J. Basic Microb. 1989, 29, 383-390. [CrossRef]

48. Fujita, T.; Inoue, K.; Yamamoto, S.; Ikumoto, T.; Sasaki, S.; Toyama, R.; Chiba, K.; Hoshino, Y.; Okumoto, T. Fungal metabolites. Part 11. A potent immunosuppressive activity found in Isaria sinclairii metabolite. J. Antibiot. 1994, 47, 208-215. [CrossRef]

49. Miyake, Y.; Kozutsumi, Y.; Nakamura, S.; Fujita, T.; Kawasaki, T. Serine palmitoyltransferase is the primary target of a sphingosine-like immunosuppressant, ISP-1/myriocin. Biochem. Bioph. Res. Co. 1995, 211, 396-403. [CrossRef]

50. Tatematsu, K.; Tanaka, Y.; Sugiyama, M.; Sudoh, M.; Mizokami, M. Host sphingolipid biosynthesis is a promising therapeutic target for the inhibition of hepatitis B virus replication. J. Med. Virol. 2011, 83, 587-593. [CrossRef]

51. Yu, S.; Jia, B.; Yang, Y.; Liu, N.; Wu, A. Involvement of PERK-CHOP pathway in fumonisin $\mathrm{B}_{1}$ - induced cytotoxicity in human gastric epithelial cells. Food Chem. Toxicol. 2020, 136. [CrossRef]

52. Liu, J.; Huang, X.; Withers, B.R.; Blalock, E.; Liu, K.; Dickson, R.C. Reducing sphingolipid synthesis orchestrates global changes to extend yeast lifespan. Aging Cell 2013, 12, 833-841. [CrossRef] [PubMed]

53. Reforgiato, M.R.; Milano, G.; Fabriàs, G.; Casas, J.; Gasco, P.; Paroni, R.; Samaja, M.; Ghidoni, R.; Caretti, A.; Signorelli, P. Inhibition of ceramide de novo synthesis as a postischemic strategy to reduce myocardial reperfusion injury. Basic Res. Cardiol. 2016, 111. [CrossRef] [PubMed]

54. Horn, W.S.; Smith, J.L.; Bills, G.F.; Raghoobar, S.L.; Helms, G.L.; Kurtz, M.B.; Marrinan, J.A.; Frommer, B.R.; Thornton, R.A.; Mandala, S.M. Sphingofungins E and F: Novel serinepalmitoyl trans-ferase inhibitors from Paecilomyces variotii. J. Antibiot. 1992, 45, 1692-1696. [CrossRef] [PubMed] 
55. VanMiddlesworth, F.; Giacobbe, R.A.; Lopez, M.; Garrity, G.; Bland, J.A.; Bartizal, K.; Fromtling, R.A.; Polishook, J.; Zweerink, M.; Edison, A.M.; et al. Sphingofungins a, b, c, and d; a new family of antifungal agents: I. Fermentation, isolation, and biological activity. J. Antibiot. 1992, 45, 861-867. [CrossRef] [PubMed]

56. Song, Z.; Liu, Y.; Gao, J.; Hu, J.; He, H.; Dai, S.; Wang, L.; Dai, H.; Zhang, L.; Song, F. Antitubercular metabolites from the marine-derived fungus strain Aspergillus fumigatus MF029. Nat. Prod. Res. 2019. [CrossRef]

57. Zhang, H.; Zhu, H.T.; Wang, D.; Yang, C.R.; Zhang, Y.J. Sphingofungins G and H: New five-membered lactones from Aspergillus penicilliodes Speg. Nat. Prod. Res. 2019, 33, 1284-1291. [CrossRef] [PubMed]

58. Hanada, K.; Nishijima, M.; Fujita, T.; Kobayashi, S. Specificity of inhibitors of serine palmitoyltransferase (SPT), a key enzyme in sphingolipid biosynthesis, in intact cells. A novel evaluation system using an SPT-defective mammalian cell mutant. Biochem. Pharmacol. 2000, 59, 1211-1216. [CrossRef]

59. Harris, G.H.; Turner Jones, E.T.; Meinz, M.S.; Nallin-Omstead, M.; Helms, G.L.; Bills, G.F.; Zink, D.; Wilson, K.E. Isolation and structure elucidation of viridiofungins A, B and C. Tetrahedron Lett. 1993, 34, 5235-5238. [CrossRef]

60. Mandala, S.M.; Thornton, R.A.; Frommer, B.R.; Dreikorn, S.; Kurtz, M.B. Viridiofungins, novel inhibitors of sphingolipid synthesis. J. Antibiot 1997, 50, 339-343. [CrossRef]

61. El-Hasan, A.; Walker, F.; Schöne, J.; Buchenauer, H. Detection of viridiofungin A and other antifungal metabolites excreted by Trichoderma harzianum active against different plant pathogens. Eur. J. Plant Pathol. 2009, 124, 457-470. [CrossRef]

62. Abbas, H.K.; Duke, S.O.; Merrill, A.H., Jr.; Wang, E.; Shier, W.T. Phytotoxicity of Australifungin, AAL-toxins and fumonisin B1 to Lemna pausicostata. Phytochemistry 1998, 47, 1509-1514. [CrossRef]

63. Mandala, S.M.; Thornton, R.A.; Frommer, B.R.; Curotto, J.E.; Rozdilsky, W.; Kurtz, M.B.; Giacobbe, R.A.; Bills, G.F.; Cabello, M.A. The Discovery of Australifungin, a Novel Inhibitor of Sphinganine N-Acyltransferase from Sporormiella australis Producing Organism, Fermentation, Isolation, and Biological Activity. J. Antibiot. 1995, 48, 349-356. [CrossRef]

64. Uhlig, S.; Petersen, D.; Flåøyen, A.; Wilkins, A. 2-Amino-14,16-dimethyloctadecan-3-ol, a new sphingosine analogue toxin in the fungal genus Fusarium. Toxicon 2005, 46, 513-522. [CrossRef] [PubMed]

65. Marrouchi, R.; Benoit, E.; Le Caer, J.P.; Belayouni, N.; Belghith, H.; Molgó, J.; Kharrat, R. Toxic C17-sphinganine analogue mycotoxin, contaminating Tunisian mussels, causes flaccid paralysis in rodents. Mar. Drugs 2013, 11, 4724-4740. [CrossRef] [PubMed]

66. Mirocha, C.J.; Gilchrist, D.G.; Shier, W.T.; Abbas, H.K.; Wen, Y.; Vesonder, R.F. AAL Toxins, funionisms (biology and chemistry) and host-specificity concepts. Mycopathologia 1992, 117, 47-56. [CrossRef] [PubMed]

67. Shier, W.T.; Abbas, H.K.; Mirocha, C.J. Toxicity of the mycotoxins fumonisins $B_{1}$ and $B_{2}$ and Alternaria alternata f. sp. lycopersici toxin (AAL) in cultured mammalian cells. Mycopathologia 1991, 116, 97-104. [CrossRef]

68. Van Der Westhuizen, L.; Shephard, G.S.; Snyman, S.D.; Abel, S.; Swanevelder, S.; Gelderblom, W.C.A. Inhibition of sphingolipid biosynthesis in rat primary hepatocyte cultures by fumonisin $\mathrm{B}_{1}$ and other structurally related compounds. Food Chem. Toxicol. 1998, 36, 497-503. [CrossRef]

69. Abbas, H.K.; Mulrooney, J.E. Effect of Some Phytopathogenic Fungi and Their Metabolites on Growth of Heliothis virescens (F.) and Its Host Plants. Biocontrol Sci. Techn. 1994, 4, 77-87. [CrossRef]

70. Gelderblom, W.C.A.; Cawood, M.E.; Snyman, S.D.; Vleggaar, R.; Marasas, W.F.O. Structure-activity relationships of fumonisins in short-term carcinogenesis and cytotoxicity assays. Food Chem. Toxicol. 1993, 31, 407-414. [CrossRef]

71. Tanaka, T.; Abbas, H.K.; Duke, S.O. Structure-dependent phytotoxicity of fumonisins and related compounds in a duckweed bioassay. Phytochemistry 1993, 33, 779-785. [CrossRef]

72. Siler, D.J.; Gilchrist, D.G. Properties of host specific toxins produced by Alternaria alternata f. sp. lycopersici in culture and in tomato plants. Physiol. Plant Pathol. 1983, 23, 265-274. [CrossRef]

73. Norred, W.P.; Riley, R.T.; Meredith, F.I.; Poling, S.M.; Plattner, R.D. Instability of N-acetylated fumonisin $\mathrm{B}_{1}\left(\mathrm{FA}_{1}\right)$ and the impact on inhibition of ceramide synthase in rat liver slices. Food Chem. Toxicol. 2001, 39, 1071-1078. [CrossRef]

74. Shier, W.T.; Abbas, H.K. Current issues in research on fumonisins, mycotoxins which may cause nephropathy. J. Toxicol. Toxin Rev. 1999, 18, 323-335. [CrossRef] 
75. Shier, W.T.; Abbas, H.K.; Abou-Karam, M.; Badria, F.A.; Resch, P.A. Fumonisins: Abiogenic Conversions of an Environmental Tumor Promoter and Common Food Contaminant. J. Toxicol. Toxin Rev. 2003, 22, 591-616. [CrossRef]

76. Savard, M.E.; Sinha, R.C.; Lau, R.; Séguin, C.; Buffam, S. Monoclonal antibodies for fumonisins $B_{1}, B_{2}$ and $B_{3}$. Food Agric. Immunol. 2003, 15, 127-134. [CrossRef]

77. Azaiez, I.; Meca, G.; Manyes, L.; Luciano, F.B.; Fernández-Franzón, M. Study of the chemical reduction of the fumonisins toxicity using allyl, benzyl and phenyl isothiocyanate in model solution and in food products. Toxicon 2013, 63, 137-146. [CrossRef]

78. $\quad$ Lamprecht, S.C.; Marasas, W.F.O.; Alberts, J.F.; Cawood, M.E.; Gelderblom, W.C.A.; Shephard, G.S.; Thiel, P.G.; Calitz, F.J. Phytotoxicity of fumonisins and TA-toxin to corn and tomato. Phytopathology 1994, 84, 383-391. [CrossRef]

79. Vesonder, R.F.; Peterson, R.E.; Labeda, D.; Abbas, H.K. Comparative phytotoxicity of the fumonisins, AAL-toxin and yeast sphingolipids in Lemna minor L. (duckweed). Arch. Environ. Con. Tox. 1992, 23, 464-467. [CrossRef]

80. Voss, K.A.; Riley, R.T.; Snook, M.E.; Gelineau-van Waes, J. Reproductive and sphingolipid metabolic effects of fumonisin $\mathrm{B}_{1}$ and its alkaline hydrolysis product in $\mathrm{LM} / \mathrm{Bc}$ mice: Hydrolyzed fumonisin $\mathrm{B}_{1}$ did not cause neural tube defects. Toxicol. Sci. 2009, 112, 459-467. [CrossRef]

81. Grenier, B.; Bracarense, A.P.F.L.; Schwartz, H.E.; Trumel, C.; Cossalter, A.M.; Schatzmayr, G.; Kolf-Clauw, M.; Moll, W.D.; Oswald, I.P. The low intestinal and hepatic toxicity of hydrolyzed fumonisin $B_{1}$ correlates with its inability to alter the metabolism of sphingolipids. Biochem. Pharmacol. 2012, 83, 1465-1473. [CrossRef]

82. Gu, M.J.; Han, S.E.; Hwang, K.; Mayer, E.; Reisinger, N.; Schatzmayr, D.; Park, B.C.; Han, S.H.; Yun, C.H. Hydrolyzed fumonisin $B_{1}$ induces less inflammatory responses than fumonisin $B_{1}$ in the co-culture model of porcine intestinal epithelial and immune cells. Toxicol. Lett. 2019, 305, 110-116. [CrossRef] [PubMed]

83. Seiferlein, M.; Humpf, H.U.; Voss, K.A.; Sullards, M.C.; Allegood, J.C.; Wang, E.; Merrill, A.H., Jr. Hydrolyzed fumonisins $\mathrm{HFB}_{1}$ and $\mathrm{HFB}_{2}$ are acylated in vitro and in vivo by ceramide synthase to form cytotoxic N-acyl-metabolites. Mol. Nutr. Food Res. 2007, 51, 1120-1130. [CrossRef]

84. Seefelder, W.; Knecht, A.; Humpf, H.U. Bound fumonisin $\mathrm{B}_{1}$ : Analysis of fumonisin- $\mathrm{B}_{1}$ glyco and amino acid conjugates by liquid chromatography-electrospray ionization-tandem mass spectrometry. J. Agric. Food Chem. 2003, 51, 5567-5573. [CrossRef] [PubMed]

85. Abbas, H.K.; Tanaka, T.; Duke, S.O.; Porter, J.K.; Wray, E.M.; Hodges, L.; Sessions, A.E.; Wang, E.; Merrill Jnr, A.H.; Riley, R.T. Fumonisin- and AAL-toxin-induced disruption of sphingolipid metabolism with accumulation of free sphingoid bases. Plant Physiol. 1994, 106, 1085-1093. [CrossRef] [PubMed]

86. Henriques, J.; Lima, M.; Rosa, S.; Dias, A.S.; Dias, L.S. Allelopathic plants. XVIII. Solanum nigrum L. Allelopathy J. 2006, 17, 1-15.

87. Duke, S.O.; Dayan, F.E. Modes of action of microbially-produced phytotoxins. Toxins 2011, 3, $1038-1064$. [CrossRef]

88. Abbas, H.K.; Tanaka, T.; Shier, W.T. Biological activities of synthetic analogues of Alternaria alternata toxin (AAL-toxin) and fumonisin in plant and mammalian cell cultures. Phytochemistry 1995, 40, 1681-1689. [CrossRef]

89. Duke, S.O.; Dayan, F.E. Clues to new herbicide mechanisms of action from natural sources. ACS Symposium Series 2013, 1141, 203-215. [CrossRef]

90. Luo, Y.; Liu, X.; Li, J. Updating techniques on controlling mycotoxins-A review. Food Control 2018, 89, 123-132. [CrossRef]

91. McCormick, S.P. Microbial Detoxification of Mycotoxins. J. Chem. Ecol. 2013, 39, 907-918. [CrossRef]

92. Agriopoulou, S.; Stamatelopoulou, E.; Varzakas, T. Advances in occurrence, importance, and mycotoxin control strategies: Prevention and detoxification in foods. Foods 2020, 9, 137. [CrossRef] [PubMed]

93. Norred, W.P.; Voss, K.A.; Bacon, C.W.; Riley, R.T. Effectiveness of ammonia treatment in detoxification of fumonisin-contaminated corn. Food Chem. Toxicol. 1991, 29, 815-819. [CrossRef]

94. Chourasia, H.K. Efficacy of ammonia in detoxification of fumonisin contaminated corn. Indian J. Exp. Biol. 2001, 39, 493-495.

95. De Girolamo, A.; Lattanzio, V.M.T.; Schena, R.; Visconti, A.; Pascale, M. Effect of alkaline cooking of maize on the content of fumonisins $B_{1}$ and $B_{2}$ and their hydrolysed forms. Food Chem. 2016, 192, 1083-1089. [CrossRef] [PubMed] 
96. Chang, X.; Wang, J.; Sun, C.; Liu, H.; Wu, S.; Sun, J.; Wu, Z. Research on degradation of chlorine dioxide in primary mycotoxins. J. Chin. Cereals Oils Assoc. 2016, 31, 113-118.

97. Voss, K.; Ryu, D.; Jackson, L.; Riley, R.; Gelineau-Van Waes, J. Reduction of Fumonisin Toxicity by Extrusion and Nixtamalization (Alkaline Cooking). J. Agric. Food Chem. 2017, 65, 7088-7096. [CrossRef] [PubMed]

98. ten Bosch, L.; Pfohl, K.; Avramidis, G.; Wieneke, S.; Viöl, W.; Karlovsky, P. Plasma-based degradation of mycotoxins produced by Fusarium, Aspergillus and Alternaria species. Toxins 2017, 9, 97. [CrossRef] [PubMed]

99. Wielogorska, E.; Ahmed, Y.; Meneely, J.; Graham, W.G.; Elliott, C.T.; Gilmore, B.F. A holistic study to understand the detoxification of mycotoxins in maize and impact on its molecular integrity using cold atmospheric plasma treatment. Food Chem. 2019, 301. [CrossRef] [PubMed]

100. Afsah-Hejri, L.; Hajeb, P.; Ehsani, R.J. Application of ozone for degradation of mycotoxins in food: A review. Compr. Rev. Food Sci. Food Saf. 2020, 19, 1777-1808. [CrossRef]

101. Milani, J.; Maleki, G. Effects of processing on mycotoxin stability in cereals. J. Sci. Food Agric. 2014, 94, 2372-2375. [CrossRef] [PubMed]

102. Jard, G.; Liboz, T.; Mathieu, F.; Guyonvarch, A.; Lebrihi, A. Review of mycotoxin reduction in food and feed: From prevention in the field to detoxification by adsorption or transformation. Food Addit. Contam. A 2011, 28, 1590-1609. [CrossRef] [PubMed]

103. Benedetti, R.; Nazzi, F.; Locci, R.; Firrao, G. Degradation of fumonisin $B_{1}$ by a bacterial strain isolated from soil. Biodegradation 2006, 17, 31-38. [CrossRef]

104. Heinl, S.; Hartinger, D.; Thamhesl, M.; Vekiru, E.; Krska, R.; Schatzmayr, G.; Moll, W.D.; Grabherr, R. Degradation of fumonisin $B_{1}$ by the consecutive action of two bacterial enzymes. J. Biotechnol. 2010, 145, 120-129. [CrossRef]

105. Chlebicz, A.; Śliżewska, K. In Vitro Detoxification of Aflatoxin $B_{1}$, Deoxynivalenol, Fumonisins, T-2 Toxin and Zearalenone by Probiotic Bacteria from Genus Lactobacillus and Saccharomyces cerevisiae Yeast. Probiotics Antimicro. 2020, 12, 289-301. [CrossRef] [PubMed]

106. Burgess, K.M.N.; Renaud, J.B.; McDowell, T.; Sumarah, M.W. Mechanistic Insight into the Biosynthesis and Detoxification of Fumonisin Mycotoxins. ACS Chem. Biol. 2016, 11, 2618-2625. [CrossRef] [PubMed]

107. Azam, M.S.; Yu, D.; Wu, A. Enzymes for degradation of Fusarium mycotoxins. In Food Safety E Mycotoxins; Wu, A., Ed.; Springer: Singapore, 2019; pp. 113-135. [CrossRef]

108. Alberts, J.; Schatzmayr, G.; Moll, W.D.; Davids, I.; Rheeder, J.; Burger, H.M.; Shephard, G.; Gelderblom, W. Detoxification of the fumonisin mycotoxins in maize: An enzymatic approach. Toxins 2019, 11,523. [CrossRef] [PubMed]

109. Hartinger, D.; Schwartz, H.; Hametner, C.; Schatzmayr, G.; Haltrich, D.; Moll, W.D. Enzyme characteristics of aminotransferase FumI of Sphingopyxis sp. MTA144 for deamination of hydrolyzed fumonisin $\mathrm{B}_{1}$. Appl. Microbiol. Biot. 2011, 91, 757-768. [CrossRef]

110. Masching, S.; Naehrer, K.; Schwartz-Zimmermann, H.E.; Sărăndan, M.; Schaumberger, S.; Dohnal, I.; Nagl, V.; Schatzmayr, D. Gastrointestinal degradation of fumonisin $B_{1}$ by carboxylesterase FumD prevents fumonisin induced alteration of sphingolipid metabolism in Turkey and swine. Toxins 2016, 8, 84. [CrossRef]

111. Schertz, H.; Kluess, J.; Frahm, J.; Schatzmayr, D.; Dohnal, I.; Bichl, G.; Schwartz-Zimmermann, H.; Breves, G.; Dänicke, S. Oral and intravenous fumonisin exposure in pigs-a single-dose treatment experiment evaluating toxicokinetics and detoxification. Toxins 2018, 10, 150. [CrossRef]

112. Loi, M.; Fanelli, F.; Cimmarusti, M.T.; Mirabelli, V.; Haidukowski, M.; Logrieco, A.F.; Caliandro, R.; Mule, G. In vitro single and combined mycotoxins degradation by Ery4 laccase from Pleurotus eryngii and redox mediators. Food Control 2018, 90, 401-406. [CrossRef]

113. Wang, X.; Qin, X.; Hao, Z.; Luo, H.; Yao, B.; Su, X. Degradation of four major mycotoxins by eight manganese peroxidases in presence of a dicarboxylic acid. Toxins 2019, 11, 566. [CrossRef] [PubMed]

114. Avantaggaito, G.; Solfrizzo, M.; Visconti, A. Recent advances on the use of adsorbent materials for detoxification of Fusarium mycotoxins. Food Addit. Contam. 2005, 22, 379-388. [CrossRef] [PubMed]

115. Brown, K.A.; Mays, T.; Romoser, A.; Marroquin-Cardona, A.; Mitchell, N.J.; Elmore, S.E.; Phillips, T.D. Modified hydra bioassay to evaluate the toxicity of multiple mycotoxins and predict the detoxification efficacy of a clay-based sorbent. J. Appl. Toxicol. 2014, 34, 40-48. [CrossRef] [PubMed]

116. Yuan, C.W.; Huang, J.T.; Chen, C.C.; Tang, P.C.; Huang, J.W.; Lin, J.J.; Huang, S.Y.; Chen, S.E. Evaluation of Efficacy and Toxicity of Exfoliated Silicate Nanoclays as a Feed Additive for Fumonisin Detoxification. J. Agric. Food Chem. 2017, 65, 6564-6571. [CrossRef] [PubMed] 
117. Beekrum, S.; Govinden, R.; Padayachee, T.; Odhav, B. Naturally occurring phenols: A detoxification strategy for fumonisin B1. Food Addit. Contam. 2003, 20, 490-493. [CrossRef]

118. Siddoo-Atwal, C.; Atwal, A.S. A possible role for honey bee products in the detoxification of mycotoxins. Acta Hortic. 2012, 963, 237-245. [CrossRef]

119. Xing, F.; Hua, H.; Selvaraj, J.N.; Yuan, Y.; Zhao, Y.; Zhou, L.; Liu, Y. Degradation of fumonisin B $B_{1}$ by cinnamon essential oil. Food Control 2014, 38,37-40. [CrossRef]

120. Gilchrist, D.G. Mycotoxins reveal connections between plants and animals in apoptosis and ceramide signaling. Cell Death Differ. 1997, 4, 689-698. [CrossRef]

121. Jacobson, M.D.; Weil, M.; Raff, M.C. Programmed cell death in animal development. Cell 1997, 88, $347-354$. [CrossRef]

122. Green, D.R. The Coming Decade of Cell Death Research: Five Riddles. Cell 2019, 177, 1094-1107. [CrossRef]

123. Das, A.; Kawai-Yamada, M.; Uchimiya, H. Programmed cell death in plants. In Abiotic Stress Adaptation in Plants: Physiological, Molecular and Genomic Foundation; Pareek, A., Sopory, S.K., Bohnert, H.J., Govindjee, Eds.; Springer: Amsterdam, The Netherlands, 2010; pp. 371-383. [CrossRef]

124. Bedoui, S.; Herold, M.J.; Strasser, A. Emerging connectivity of programmed cell death pathways and its physiological implications. Nat. Rev. Mol. Cell Biol. 2020, 21, 678-695. [CrossRef] [PubMed]

125. Rantong, G.; Gunawardena, A.H.L.A.N. Programmed cell death: Genes involved in signaling, regulation, and execution in plants and animals. Botany 2015, 93, 193-210. [CrossRef]

126. Valandro, F.; Menguer, P.K.; Cabreira-Cagliari, C.; Margis-Pinheiro, M.; Cagliari, A. Programmed cell death (PCD) control in plants: New insights from the Arabidopsis thaliana deathosome. Plant Sci. 2020, 299. [CrossRef] [PubMed]

127. Slotte, J.P. Biological functions of sphingomyelins. Prog. Lipid Res. 2013, 52, 424-437. [CrossRef]

128. Luttgeharm, K.D.; Kimberlin, A.N.; Cahoon, E.B. Plant sphingolipid metabolism and function. Subcell. Biochem. 2016, 86, 249-286. [CrossRef]

129. Chao, M.V. Ceramide: A potential second messenger in the nervous system. Mol. Cell. Neurosci. 1995, 6, 91-96. [CrossRef]

130. Ng, C.K.Y.; Carr, K.; McAinsh, M.R.; Powell, B.; Hetherington, A.M. Drought-induced guard cell signal transduction involves sphingosine-1-phosphate. Nature 2001, 410, 596-599. [CrossRef]

131. Lynch, D.V. Evidence that sphingolipid signaling is involved in responding to low temperature. New Phytol. 2012, 194, 7-9. [CrossRef]

132. Dixon, S.C.; Soriano, B.J.; Lush, R.M.; Borner, M.M.; Figg, W.D. Apoptosis: Its role in the development of malignancies and its potential as a novel therapeutic target. Annu. Pharmacother. 1997, 31, 76-82. [CrossRef]

133. Govindarajah, N.; Clifford, R.; Bowden, D.; Sutton, P.A.; Parsons, J.L.; Vimalachandran, D. Sphingolipids and acid ceramidase as therapeutic targets in cancer therapy. Crit. Rev. Oncol. Hemat. 2019, 138, $104-111$. [CrossRef]

134. Magnin-Robert, M.; Le Bourse, D.; Markham, J.; Dorey, S.; Clément, C.; Baillieul, F.; Dhondt-Cordelier, S. Modifications of sphingolipid content affect tolerance to hemibiotrophic and necrotrophic pathogens by modulating plant defense responses in Arabidopsis. Plant Physiol. 2015, 169, 2255-2274. [CrossRef] [PubMed]

135. Zhou, D.R.; Eid, R.; Boucher, E.; Miller, K.A.; Mandato, C.A.; Greenwood, M.T. Stress is an agonist for the induction of programmed cell death: A review. BBA-Mol. Cell Res. 2019, 1866, 699-712. [CrossRef]

136. Wong, K.; Li, X.B.; Hunchuk, N. N-acetylsphingosine (C2-ceramide) inhibited neutrophil superoxide formation and calcium influx. J. Biol. Chem. 1995, 270, 3056-3062. [CrossRef]

137. Bi, F.C.; Liu, Z.; Wu, J.X.; Liang, H.; Xi, X.L.; Fang, C.; Sun, T.J.; Yin, J.; Dai, G.Y.; Rong, C.; et al. Loss of ceramide kinase in Arabidopsis impairs defenses and promotes ceramide accumulation and mitochondrial $\mathrm{H}_{2} \mathrm{O}_{2}$ burstsc w. Plant Cell 2014, 26, 3449-3469. [CrossRef]

138. Townley, H.E.; McDonald, K.; Jenkins, G.I.; Knight, M.R.; Leaver, C.J. Ceramides induce programmed cell death in Arabidopsis cells in a calcium-dependent manner. Biol. Chem. 2005, 386, 161-166. [CrossRef] [PubMed]

139. Lachaud, C.; Prigent, E.; Thuleau, P.; Grat, S.; Da Silva, D.; Brière, C.; Mazars, C.; Cotelle, V. 14-3-3-Regulated Ca 2+-dependent protein kinase CPK3 is required for sphingolipid-induced cell death in Arabidopsis. Cell Death Differ. 2013, 20, 209-217. [CrossRef] [PubMed]

140. Greenberg, J.T.; Silverman, F.P.; Liang, H. Uncoupling salicylic acid-dependent cell death and defense-related responses from disease resistance in the Arabidopsis mutant acd5. Genetics 2000, 156, 341-350. [PubMed] 
141. Liang, H.; Yao, N.; Song, J.T.; Luo, S.; Lu, H.; Greenberg, J.T. Ceramides modulate programmed cell death in plants. Gene. Dev. 2003, 17, 2636-2641. [CrossRef]

142. Simanshu, D.K.; Zhai, X.; Munch, D.; Hofius, D.; Markham, J.E.; Bielawski, J.; Bielawska, A.; Malinina, L.; Molotkovsky, J.G.; Mundy, J.W.; et al. Arabidopsis accelerated cell death 11, ACD11, Is a ceramide-1-phosphate transfer protein and intermediary regulator of phytoceramide levels. Cell Rep. 2014, 6, 388-399. [CrossRef]

143. Kim, S.; Fyrst, H.; Saba, J. Accumulation of phosphorylated sphingoid long chain bases results in cell growth inhibition in Saccharomyces cerevisiae. Genetics 2000, 156, 1519-1529. [PubMed]

144. Nagano, M.; Takahara, K.; Fujimoto, M.; Tsutsumi, N.; Uchimiya, H.; Kawai-Yamada, M. Arabidopsis sphingolipid fatty acid 2-hydroxylases (AtFAH1 and AtFAH2) are functionally differentiated in fatty acid 2-hydroxylation and stress responses. Plant Physiol. 2012, 159, 1138-1148. [CrossRef] [PubMed]

145. Wang, H.; Li, J.; Bostock, R.M.; Gilchrist, D.G. Apoptosis: A functional paradigm for programmed plant cell death induced by a host-selective phytotoxin and invoked during development. Plant Cell 1996, 8, 375-391. [CrossRef]

146. Asai, T.; Stone, J.M.; Heard, J.E.; Kovtun, Y.; Yorgey, P.; Sheen, J.; Ausubel, F.M. Fumonisin B1-induced cell death in Arabidopsis protoplasts requires jasmonate-, ethylene-, and salicylate-dependent signaling pathways. Plant Cell 2000, 12, 1823-1835. [CrossRef]

147. Stone, J.M.; Heard, J.E.; Asai, T.; Ausubel, F.M. Simulation of fungal-mediated cell death by fumonisin B1 and selection of fumonisin B1-resistant (fbr) Arabidopsis mutants. Plant Cell 2000, 12, 1811-1822. [CrossRef]

148. Wang, H.; Jones, C.; Ciacci-Zanella, J.; Holt, T.; Gilchrist, D.G.; Dickman, M.B. Fumonisins and Alternaria alternata lycopersici toxins: Sphinganine analog mycotoxins induce apoptosis in monkey kidney cells. Proc. Natl. Acad. Sci. USA 1996, 93, 3461-3465. [CrossRef] [PubMed]

149. Wang, E.; Norred, W.P.; Bacon, C.W.; Riley, R.T.; Merrill, A.H., Jr. Inhibition of sphingolipid biosynthesis by fumonisins. Implications for diseases associated with Fusarium moniliforme. J. Biol. Chem. 1991, 266, 14486-14490. [PubMed]

150. Merrill, A.H.; Wang, E.; Gilchrist, D.G.; Riley, R.T. Fumonisins and other inhibitors of de novo sphingolipid biosynthesis. Adv. Lipid Res. 1993, 26, 215-234. [PubMed]

151. Gilchrist, D.G.; Wang, H.; Bostock, R.M. Sphingosine-related mycotoxins in plant and animal diseases. Can. J. Bot. 1995, 73, s459-s467. [CrossRef]

152. Merrill, A.H., Jr.; Liotta, D.C.; Riley, R.I. Fumonisins: Fungal toxins that shed light on sphingolipid function. Trends Cell Biol. 1996, 6, 218-223. [CrossRef]

153. Markham, J.E.; Molino, D.; Gissot, L.; Bellec, Y.; Hématy, K.; Marion, J.; Belcram, K.; Palauqui, J.C.; Satiat-Jeunemaître, B.; Faure, J.D. Sphingolipids containing very-long-chain fatty acids define a secretory pathway for specific polar plasma membrane protein targeting in Arabidopsis. Plant Cell 2011, 23, 2362-2378. [CrossRef]

154. Ternes, P.; Feussner, K.; Werner, S.; Lerche, J.; Iven, T.; Heilmann, I.; Riezman, H.; Feussner, I. Disruption of the ceramide synthase LOH1 causes spontaneous cell death in Arabidopsis thaliana. New Phytol. 2011, 192, 841-854. [CrossRef]

155. Moussatos, V.V.; Yang, S.F.; Ward, B.; Gilchrist, D.G. AAL-toxin induced physiological changes in lycopersicon esculentum mill: Roles for ethylene and pyrimidine intermediates in necrosis. Physiol. Mol. Plant Pathol. 1994, 44, 455-468. [CrossRef]

156. Moore, T.; Martineau, B.; Bostock, R.M.; Lincoln, J.E.; Gilchrist, D.G. Molecular and genetic characterization of ethylene involvement in mycotoxin-induced plant cell death. Physiol. Mol. Plant Pathol. 1999, 54, 73-85. [CrossRef]

157. Gechev, T.S.; Gadjev, I.Z.; Hille, J. An extensive microarray analysis of AAL-toxin-induced cell death in Arabidopsis thaliana brings new insights into the complexity of programmed cell death in plants. Cell. Mol. Life Sci. 2004, 61, 1185-1197. [CrossRef]

158. Mase, K.I.; Mizuno, T.; Ishihama, N.; Fujii, T.; Mori, H.; Kodama, M.; Yoshioka, H. Ethylene signaling pathway and MAPK cascades are required for AAL toxin-induced Programmed cell death. Mol. Plant Microbe Interact. 2012, 25, 1015-1025. [CrossRef]

159. Sultana, A.; Boro, P.; Mandal, K.; Chattopadhyay, S. AAL-toxin induced stress in Arabidopsis thaliana is alleviated through GSH-mediated salicylic acid and ethylene pathways. Plant Cell Tiss. Org. 2020, 141, 299-314. [CrossRef] 
160. Egusa, M.; Ozawa, R.; Takabayashi, J.; Otani, H.; Kodama, M. The jasmonate signaling pathway in tomato regulates susceptibility to a toxin-dependent necrotrophic pathogen. Planta 2009, 229, 965-976. [CrossRef] [PubMed]

161. Zhang, L.; Jia, C.; Liu, L.; Zhang, Z.; Li, C.; Wang, Q. The involvement of jasmonates and ethylene in Alternaria alternata f. sp. lycopersici toxin-induced tomato cell death. J. Exp. Bot. 2011, 62, 5405-5418. [CrossRef] [PubMed]

162. Zhang, M.; Koh, J.; Liu, L.; Shao, Z.; Liu, H.; Hu, S.; Zhu, N.; Dufresne, C.P.; Chen, S.; Wang, Q. Critical Role of COI1-Dependent Jasmonate Pathway in AAL toxin induced PCD in Tomato Revealed by Comparative Proteomics. Sci. Rep. 2016, 6. [CrossRef]

163. Witsenboer, H.M.A.; van de Griend, E.G.; Tiersma, J.B.; Nijkamp, H.J.J.; Hille, J. Tomato resistance to Alternaria stem canker: Localization in host genotypes and functional expression compared to non-host resistance. Theor. Appl. Genet. 1989, 78, 457-462. [CrossRef] [PubMed]

164. Van Der Biezen, E.A.; Nijkamp, H.J.J.; Hille, J. Mutations at the Asc locus of tomato confer resistance to the fungal pathogen Alternaria alternata f. sp. lycopersici. Theor. Appl. Genet. 1996, 92, 898-904. [CrossRef] [PubMed]

165. Brandwagt, B.F.; Kneppers, T.J.A.; John, J.H.; Nijkamp, H.J.J.; Hille, J. Overexpression of the tomato Asc-1 gene mediates high insensitivity to AAL toxins and fumonisin B1 in tomato hairy roots and confers resistance to Alternaria alternata f. sp. lycopersici in Nicotiana umbratica plants. Mol. Plant Microbe Interact. 2002, 15, 35-42. [CrossRef]

166. Brandwagt, B.F.; Mesbah, L.A.; Takken, F.L.W.; Laurent, P.L.; Kneppers, T.J.A.; Hille, J.; Nijkamp, H.J.J. A longevity assurance gene homolog of tomato mediates resistance to Altemaria alternata f. sp. lycopersici toxins and fumonisin B1. Proc. Natl. Acad. Sci. USA 2000, 97, 4961-4966. [CrossRef]

167. Brandwagt, B.F.; Kneppers, T.J.A.; Van der Weerden, G.M.; Nijkamp, H.J.J.; Hille, J. Most AAL toxin-sensitive Nicotiana species are resistant to the tomato fungal pathogen Alternaria alternata f. sp. lycopersici. Mol. Plant Microbe Interact. 2001, 14, 460-470. [CrossRef]

168. Egusa, M.; Miwa, T.; Kaminaka, H.; Takano, Y.; Kodama, M. Nonhost resistance of Arabidopsis thaliana against Alternaria alternata involves both pre- and postinvasive defenses but is collapsed by AAL-toxin in the absence of LOH2. Phytopathology 2013, 103, 733-740. [CrossRef] [PubMed]

169. Tsuge, T.; Harimoto, Y.; Akimitsu, K.; Ohtani, K.; Kodama, M.; Akagi, Y.; Egusa, M.; Yamamoto, M.; Otani, H. Host-selective toxins produced by the plant pathogenic fungus Alternaria alternata. FEMS Microbiol. Rev. 2012, 37, 44-66. [CrossRef] [PubMed]

170. de Zélicourt, A.; Montiel, G.; Pouvreau, J.B.; Thoiron, S.; Delgrange, S.; Simier, P.; Delavault, P. Susceptibility of Phelipanche and Orobanche species to AAL-toxin. Planta 2009, 230, 1047-1055. [CrossRef]

171. Lincoln, J.E.; Richael, C.; Overduin, B.; Smith, K.; Bostock, R.; Gilchrist, D.G. Expression of the antiapoptotic baculovirus $\mathrm{p} 35$ gene in tomato blocks programmed cell death and provides broad-spectrum resistance to disease. Proc. Natl. Acad. Sci. USA 2002, 99, 15217-15221. [CrossRef]

172. Qureshi, M.K.; Sujeeth, N.; Gechev, T.S.; Hille, J. The zinc finger protein ZAT11 modulates paraquat-induced programmed cell death in Arabidopsis thaliana. Acta Physiol. Plant. 2013, 35, 1863-1871. [CrossRef]

173. Shao, Z.; Zhao, Y.; Liu, L.; Chen, S.; Li, C.; Meng, F.; Liu, H.; Hu, S.; Wang, J.; Wang, Q. Overexpression of FBR41 enhances resistance to sphinganine analog mycotoxin-induced cell death and Alternaria stem canker in tomato. Plant Biotechnol. J. 2020, 18, 141-154. [CrossRef]

174. Al-Jaal, B.A.; Jaganjac, M.; Barcaru, A.; Horvatovich, P.; Latiff, A. Aflatoxin, fumonisin, ochratoxin, zearalenone and deoxynivalenol biomarkers in human biological fluids: A systematic literature review, 2001-2018. Food Chem. Toxicol. 2019, 129, 211-228. [CrossRef] [PubMed]

175. Alberts, J.; Rheeder, J.; Gelderblom, W.; Shephard, G.; Burger, H.M. Rural subsistence maize farming in South Africa: Risk assessment and intervention models for reduction of exposure to fumonisin mycotoxins. Toxins 2019, 11, 334. [CrossRef] [PubMed]

176. Cendoya, E.; Chiotta, M.L.; Zachetti, V.; Chulze, S.N.; Ramirez, M.L. Fumonisins and fumonisin-producing Fusarium occurrence in wheat and wheat by products: A review. J. Cereal Sci. 2018, 80, 158-166. [CrossRef]

177. Dall'Asta, C.; Battilani, P. Fumonisins and their modified forms, a matter of concern in future scenario? World Mycotoxin J. 2016, 9, 727-739. [CrossRef] 
178. Alberts, J.F.; van Zyl, W.H.; Gelderblom, W.C.A. Biologically based methods for control of fumonisin-producing Fusarium species and reduction of the fumonisins. Front. Microbiol. 2016, 7. [CrossRef]

179. Gil-Serna, J.; Vázquez, C.; Patiño, B. Genetic regulation of aflatoxin, ochratoxin A, trichothecene, and fumonisin biosynthesis: A review. Int. Microbiol. 2020, 23, 89-96. [CrossRef]

180. Santiago, R.; Cao, A.; Butrón, A. Genetic factors involved in fumonisin accumulation in maize kernels and their implications in maize agronomic management and breeding. Toxins 2015, 7, 3267-3296. [CrossRef]

181. Chavez, R.A.; Cheng, X.; Stasiewicz, M.J. A review of the methodology of analyzing aflatoxin and fumonisin in single corn kernels and the potential impacts of these methods on food security. Foods 2020, 9, 297. [CrossRef]

182. Deepa, N.; Sreenivasa, M.Y. Molecular methods and key genes targeted for the detection of fumonisin producing Fusarium verticillioides-An updated review. Food Biosci. 2019, 32. [CrossRef]

183. Santiago, R.; Cao, A.; Malvar, R.A.; Butrón, A. Genomics of maize resistance to Fusarium ear rot and fumonisin contamination. Toxins 2020, 12, 431. [CrossRef]

184. Diaz-Gomez, J.; Marin, S.; Capell, T.; Sanchis, V.; Ramos, A.J. The impact of Bacillus thuringiensis technology on the occurrence of fumonisins and other mycotoxins in maize. World Mycotoxin J. 2016, 9, 475-486. [CrossRef]

185. Sheik Abdul, N.; Marnewick, J.L. Fumonisin B1-induced mitochondrial toxicity and hepatoprotective potential of rooibos: An update. J. Appl. Toxicol. 2020. [CrossRef] [PubMed]

186. Liu, X.; Fan, L.; Yin, S.; Chen, H.; Hu, H. Molecular mechanisms of fumonisin $\mathrm{B}_{1}$-induced toxicities and its applications in the mechanism-based interventions. Toxicon 2019, 167, 1-5. [CrossRef] [PubMed]

187. Riley, R.T.; Merrill, A.H., Jr. Ceramide synthase inhibition by fumonisins: A perfect storm of perturbed sphingolipid metabolism, signaling, and disease. J. Lipid Res. 2019, 60, 1183-1189. [CrossRef]

188. Chen, C.; Riley, R.T.; Wu, F. Dietary Fumonisin and Growth Impairment in Children and Animals: A Review. Compr. Rev. Food Sci. Food Saf. 2018, 17, 1448-1464. [CrossRef]

189. Pierron, A.; Alassane-Kpembi, I.; Oswald, I.P. Impact of two mycotoxins deoxynivalenol and fumonisin on pig intestinal health. Porcine Health Manag. 2016, 2. [CrossRef]

190. Wang, X.; Wu, Q.; Wan, D.; Liu, Q.; Chen, D.; Liu, Z.; Martinez-Larrañaga, M.R.; Martínez, M.A.; Anadón, A.; Yuan, Z. Fumonisins: Oxidative stress-mediated toxicity and metabolism in vivo and in vitro. Arch. Toxicol. 2015, 90, 81-101. [CrossRef]

191. Nützmann, H.W.; Scazzocchio, C.; Osbourn, A. Metabolic gene clusters in eukaryotes. Annu. Rev. Genet. 2018, 52, 159-183. [CrossRef]

192. Seo, J.A.; Proctor, R.H.; Plattner, R.D. Characterization of four clustered and coregulated genes associated with fumonisin biosynthesis in Fusarium verticillioides. Fungal Genet. Biol. 2001, 34, 155-165. [CrossRef]

193. Proctor, R.H.; Brown, D.W.; Plattner, R.D.; Desjardins, A.E. Co-expression of 15 contiguous genes delineates a fumonisin biosynthetic gene cluster in Gibberella moniliformis. Fungal Genet. Biol. 2003, 38, 237-249. [CrossRef]

194. Butchko, R.A.E.; Plattner, R.D.; Proctor, R.H. Deletion analysis of FUM genes involved in tricarballylic ester formation during fumonisin biosynthesis. J. Agric. Food Chem. 2006, 54, 9398-9404. [CrossRef] [PubMed]

195. Proctor, R.H.; Busman, M.; Seo, J.A.; Lee, Y.W.; Plattner, R.D. A fumonisin biosynthetic gene cluster in Fusarium oxysporum strain O-1890 and the genetic basis for B versus C fumonisin production. Fungal Genet. Biol. 2008, 45, 1016-1026. [CrossRef] [PubMed]

196. Stępień, Ł.; Koczyk, G.; Waśkiewicz, A. Genetic and phenotypic variation of Fusarium proliferatum isolates from different host species. J. Appl. Genet. 2011, 52, 487-496. [CrossRef] [PubMed]

197. Janevska, S.; Ferling, I.; Jojić, K.; Rautschek, J.; Hoefgen, S.; Proctor, R.H.; Hillmann, F.; Valiante, V. Self-Protection against the Sphingolipid Biosynthesis Inhibitor Fumonisin B1 Is Conferred by a FUM Cluster-Encoded Ceramide Synthase. mBio 2020, 11. [CrossRef]

198. Brown, D.W.; Butchko, R.A.E.; Busman, M.; Proctor, R.H. The Fusarium verticillioides FUM gene cluster encodes a $\mathrm{Zn}(\mathrm{II}) 2 \mathrm{Cys} 6$ protein that affects FUM gene expression and fumonisin production. Eukaryot. Cell 2007, 6, 1210-1218. [CrossRef]

199. Desjardins, A.E.; Munkvold, G.P.; Plattner, R.D.; Proctor, R.H. FUM1-A gene required for fumonisin biosynthesis but not for maize ear rot and ear infection by Gibberella moniliformis in field tests. Mol. Plant Microbe Interact. 2002, 15, 1157-1164. [CrossRef] 
200. Proctor, R.H.; Desjardins, A.E.; Plattner, R.D.; Hohn, T.M. A polyketide synthase gene required for biosynthesis of fumonisin mycotoxins in Gibberella fujikuroi mating population A. Fungal Genet. Biol. 1999, 27, 100-112. [CrossRef]

201. Bojja, R.S.; Cerny, R.L.; Proctor, R.H.; Du, L. Determining the Biosynthetic Sequence in the Early Steps of the Fumonisin Pathway by Use of Tree Gene-Disruption Mutants of Fusarium verticillioides. J. Agric. Food Chem. 2004, 52, 2855-2860. [CrossRef]

202. Massi, F.P.; Sartori, D.; de Souza Ferranti, L.; Iamanaka, B.T.; Taniwaki, M.H.; Vieira, M.L.C.; Fungaro, M.H.P. Prospecting for the incidence of genes involved in ochratoxin and fumonisin biosynthesis in Brazilian strains of Aspergillus niger and Aspergillus welwitschiae. Int. J. Food Microbiol. 2016, 221, 19-28. [CrossRef]

203. Desjardins, A.E.; Plattner, R.D.; Proctor, R.H. Genetic and biochemical aspects of fumonisin production. Adv. Exp. Med. Biol. 1996, 392, 165-173. [CrossRef]

204. Butchko, R.A.E.; Plattner, R.D.; Proctor, R.H. FUM13 encodes a short chain dehydrogenase/reductase required for C-3 carbonyl reduction during fumonisin biosynthesis in Gibberella moniliformis. J. Agric. Food Chem. 2003, 51, 3000-3006. [CrossRef] [PubMed]

205. Butchko, R.A.E.; Plattner, R.D.; Proctor, R.H. FUM9 Is Required for C-5 Hydroxylation of Fumonisins and Complements the Meitotically Defined Fum3 Locus in Gibberella moniliformis. Appl. Environ. Microb. 2003, 69, 6935-6937. [CrossRef] [PubMed]

206. Yi, H.; Bojja, R.S.; Fu, J.; Du, L. Direct evidence for the function of FUM13 in 3-ketoreduction of mycotoxin fumonisins in Fusarium verticillioides. J. Agric. Food Chem. 2005, 53, 5456-5460. [CrossRef] [PubMed]

207. Proctor, R.H.; Plattner, R.D.; Desjardins, A.E.; Busman, M.; Butchko, R.A.E. Fumonisin production in the maize pathogen Fusarium verticillioides: Genetic basis of naturally occurring chemical variation. J. Agric. Food Chem. 2006, 54, 2424-2430. [CrossRef]

208. Pel, H.J.; De Winde, J.H.; Archer, D.B. Genome sequencing and analysis of the versatile cell factory Aspergillus niger CBS 513.88. Nat. Biotechnol. 2007, 25, 221-231. [CrossRef]

209. Rösler, S.M.; Sieber, C.M.K.; Humpf, H.U.; Tudzynski, B. Interplay between pathway-specific and global regulation of the fumonisin gene cluster in the rice pathogen Fusarium fujikuroi. Appl. Microbiol. Biotechnol. 2016, 100, 5869-5882. [CrossRef]

210. Myung, K.; Li, S.; Butchko, R.A.E.; Busman, M.; Proctor, R.H.; Abbas, H.K.; Calvo, A.M. FvVE1 regulates biosynthesis of the mycotoxins fumonisins and fusarins in Fusarium verticiliioides. J. Agric. Food Chem. 2009, 57, 5089-5094. [CrossRef]

211. Kim, H.; Woloshuk, C.P. Functional characterization of fst1 in Fusarium verticillioides during colonization of maize kernels. Mol. Plant Microbe Interact. 2011, 24, 18-24. [CrossRef]

212. Shin, J.H.; Kim, J.E.; Malapi-Wight, M.; Choi, Y.E.; Shaw, B.D.; Shim, W.B. Protein phosphatase 2A regulatory subunits perform distinct functional roles in the maize pathogen Fusarium verticillioides. Mol. Plant Pathol. 2013, 14, 518-529. [CrossRef]

213. Ridenour, J.B.; Bluhm, B.H. The novel fungal-specific gene FUG1 has a role in pathogenicity and fumonisin biosynthesis in Fusarium verticillioides. Mol. Plant Pathol. 2017, 18, 513-528. [CrossRef]

214. Niehaus, E.M.; Münsterkötter, M.; Proctor, R.H.; Brown, D.W.; Sharon, A.; Idan, Y.; Oren-Young, L.; Sieber, C.M.; Novák, O.; Pěnčík, A.; et al. Comparative "omics" of the Fusarium fujikuroi species complex highlights differences in genetic potential and metabolite synthesis. Genome Biol. Evol. 2016, 8, 3574-3599. [CrossRef] [PubMed]

215. Montis, V.; Pasquali, M.; Visentin, I.; Karlovsky, P.; Cardinale, F. Identification of a cis-acting factor modulating the transcription of FUM1, a key fumonisin-biosynthetic gene in the fungal maize pathogen Fusarium verticillioides. Fungal Genet. Biol. 2013, 51, 42-49. [CrossRef] [PubMed]

216. Kohut, G.; Ádám, A.L.; Fazekas, B.; Hornok, L. N-starvation stress induced FUM gene expression and fumonisin production is mediated via the HOG-type MAPK pathway in Fusarium proliferatum. Int. J. Food Microbiol. 2009, 130, 65-69. [CrossRef] [PubMed]

217. Medina, A.; Schmidt-Heydt, M.; Cárdenas-Chávez, D.L.; Parra, R.; Geisen, R.; Magan, N. Integrating toxin gene expression, growth and fumonisin $\mathrm{B}_{1}$ and $\mathrm{B}_{2}$ production by a strain of Fusarium verticillioides under different environmental factors. J. R. Soc. Interface 2013, 10. [CrossRef]

218. Stepień, Ł.; Waśkiewicz, A.; Wilman, K. Host extract modulates metabolism and fumonisin biosynthesis by the plant-pathogenic fungus Fusarium proliferatum. Int. J. Food Microbiol. 2015, 193, 74-81. [CrossRef] 
219. Wu, Y.; Li, T.; Gong, L.; Wang, Y.; Jiang, Y. Effects of different carbon sources on fumonisin production and fum gene expression by Fusarium proliferatum. Toxins 2019, 11, 289. [CrossRef] [PubMed]

220. Witaszak, N.; Lalak-Kańczugowska, J.; Waśkiewicz, A.; Stępień, Ł. The impacts of asparagus extract fractions on growth and fumonisins biosynthesis in Fusarium proliferatum. Toxins 2020, 12, 95. [CrossRef]

221. Johnson, L.; Harrison, J.H.; Hunt, C.; Shinners, K.; Doggett, C.G.; Sapienza, D. Nutritive value of corn silage as affected by maturity and mechanical processing: A contemporary review. J. Dairy Sci. 1999, 82, 2813-2825. [CrossRef]

222. Mansfield, M.A.; Archibald, D.D.; Jones, A.D.; Kuldau, G.A. Relationship of sphinganine analog mycotoxin contamination in maize silage to seasonal weather conditions and to agronomic and ensiling practices. Phytopathology 2007, 97, 504-511. [CrossRef]

223. Baker, S.E. Aspergillus niger genomics: Past, present and into the future. Med. Mycol. 2006, 44, 17-21. [CrossRef]

224. Brown, D.W.; Baker, S.E. Mycotoxins: A fungal genomics perspective. Methods Mol. Biol. 2017, 1542, 367-379. [CrossRef] [PubMed]

225. Noonim, P.; Mahakarnchanakul, W.; Nielsen, K.F.; Frisvad, J.C.; Samson, R.A. Fumonisin B2 production by Aspergillus niger in Thai coffee beans. Food Addit. Contam. A 2009, 26, 94-100. [CrossRef] [PubMed]

226. Månsson, M.; Klejnstrup, M.L.; Phipps, R.K.; Nielsen, K.F.; Frisvad, J.C.; Gotfredsen, C.H.; Larsen, T.O. Isolation and NMR characterization of fumonisin $\mathrm{b}_{2}$ and a new fumonisin $\mathrm{B} 6$ from aspergillus niger. J. Agric. Food Chem. 2010, 58, 949-953. [CrossRef] [PubMed]

227. Palencia, E.R.; Mitchell, T.R.; Snook, M.E.; Glenn, A.E.; Gold, S.; Hinton, D.M.; Riley, R.T.; Bacon, C.W. Analyses of black Aspergillus species of peanut and maize for ochratoxins and fumonisins. J. Food Prot. 2014, 77, 805-813. [CrossRef]

228. Desjardins, A.E.; Plattner, R.D.; Proctor, R.H. Linkage among genes responsible for fumonisin biosynthesis in Gibberella fujikuroi mating population A. Appl. Environ. Microb. 1996, 62, 2571-2576. [CrossRef]

229. Ding, Y.; Bojja, R.S.; Du, L. Fum3p, a 2-Ketoglutarate-Dependent Dioxygenase Required for C-5 Hydroxylation of Fumonisins in Fusarium verticillioides. Appl. Environ. Microb. 2004, 70, 1931-1934. [CrossRef]

230. Plattner, R.D.; Desjardins, A.E.; Leslie, J.F.; Nelson, P.E. Identification and characterization of strains of Gibberella fujikuroi mating population A with rare fumonisin production phenotypes. Mycologia 1996, 88, 416-424. [CrossRef]

231. Uhlig, S.; Busman, M.; Shane, D.S.; Rønning, H.; Rise, F.; Proctor, R. Identification of early fumonisin biosynthetic intermediates by inactivation of the FUM6 gene in Fusarium verticillioides. J. Agric. Food Chem. 2012, 60, 10293-10301. [CrossRef]

232. Li, Y.; Lou, L.; Cerny, R.L.; Butchko, R.A.E.; Proctor, R.H.; Shen, Y.; Du, L. Tricarballylic ester formation during biosynthesis of fumonisin mycotoxins in Fusarium verticillioides. Mycology 2013, 4, 179-186. [CrossRef]

233. Zaleta-Rivera, K.; Xu, C.; Yu, F.; Butchko, R.A.E.; Proctor, R.H.; Hidalgo-Lara, M.E.; Raza, A.; Dussault, P.H.; $\mathrm{Du}, \mathrm{L}$. A bidomain nonribosomal peptide synthetase encoded by FUM14 catalyzes the formation of tricarballylic esters in the biosynthesis of fumonisins. Biochemistry 2006, 45, 2561-2569. [CrossRef]

234. Brown, D.W.; Cheung, F.; Proctor, R.H.; Butchko, R.A.E.; Zheng, L.; Lee, Y.; Utterback, T.; Smith, S.; Feldblyum, T.; Glenn, A.E.; et al. Comparative analysis of 87,000 expressed sequence tags from the fumonisin-producing fungus Fusarium verticillioides. Fungal Genet. Biol. 2005, 42, 848-861. [CrossRef] [PubMed]

235. Susca, A.; Proctor, R.H.; Morelli, M.; Haidukowski, M.; Gallo, A.; Logrieco, A.F.; Moretti, A. Variation in fumonisin and ochratoxin production associated with differences in biosynthetic gene content in Aspergillus niger and A. welwitschiae isolates from multiple crop and geographic origins. Front. Microbiol. 2016, 7. [CrossRef] [PubMed]

236. Yamada, O.; Machida, M.; Hosoyama, A.; Goto, M.; Takahashi, T.; Futagami, T.; Yamagata, Y.; Takeuchi, M.; Kobayashi, T.; Koike, H.; et al. Genome sequence of Aspergillus luchuensis NBRC 4314. DNA Res. 2016, 23, 507-515. [CrossRef] [PubMed]

237. Akagi, Y.; Akamatsu, H.; Otani, H.; Kodama, M. Horizontal chromosome transfer, a mechanism for the evolution and differentiation of a plant-pathogenic fungus. Eukaryot. Cell 2009, 8, 1732-1738. [CrossRef]

238. Akagi, Y.; Taga, M.; Yamamoto, M.; Tsuge, T.; Fukumasa-Nakai, Y.; Otani, H.; Kodama, M. Chromosome constitution of hybrid strains constructed by protoplast fusion between the tomato and strawberry pathotypes of Alternaria alternata. J. Gen. Plant Pathol. 2009, 75, 101-109. [CrossRef] 
239. Akamatsu, H.; Otani, H.; Kodama, M. Characterization of a gene cluster for host-specific AAL-toxin biosynthesis in the tomato pathotype of Alternaria alternata. Fungal Genet. Rep. 2003, 50, 355. [CrossRef]

240. Zhu, X.; Vogeler, C.; Du, L. Functional complementation of fumonisin biosynthesis in FUM1-disrupted Fusarium verticillioides by the AAL-toxin Polyketide synthase gene ALT1 from Alternaria alternata f. sp. Lycopersici. J. Nat. Prod. 2008, 71, 957-960. [CrossRef]

241. Takao, K.; Akagi, Y.; Tsuge, T.; Harimoto, Y.; Yamamoto, M.; Kodama, M. The global regulator LaeA controls biosynthesis of host-specific toxins, pathogenicity and development of Alternaria alternata pathotypes. J. Gen. Plant Pathol. 2016, 82, 121-131. [CrossRef]

242. Vaquera, S.; Patriarca, A.; Cabrera, G.; Fernández Pinto, V. Temperature and water activity influence on simultaneous production of AAL toxins by Alternaria arborescens on tomato medium. Eur. J. Plant Pathol. 2017, 148, 1003-1009. [CrossRef]

243. Kroken, S.; Glass, N.L.; Taylor, J.W.; Yoder, O.C.; Turgeon, B.G. Phylogenomic analysis of type I polyketide synthase genes in pathogenic and saprobic ascomycetes. Proc. Natl. Acad. Sci. USA 2003, 100, 15670-15675. [CrossRef]

244. Condon, B.J.; Leng, Y.; Wu, D.; Bushley, K.E.; Ohm, R.A.; Otillar, R.; Martin, J.; Schackwitz, W.; Grimwood, J.; MohdZainudin, N.A.I.; et al. Comparative Genome Structure, Secondary Metabolite, and Effector Coding Capacity across Cochliobolus Pathogens. PLoS Genet. 2013, 9. [CrossRef] [PubMed]

245. Kim, H.S.; Lohmar, J.M.; Busman, M.; Brown, D.W.; Naumann, T.A.; Divon, H.H.; Uhlig, S.; Proctor, R.H. Identification and distribution of gene clusters required for synthesis of sphingolipid metabolism inhibitors in diverse species of the filamentous fungus Fusarium. BMC Genom. 2020, 21. [CrossRef]

246. Sultana, S.; Kitajima, M.; Kobayashi, H.; Nakagawa, H.; Shimizu, M.; Kageyama, K.; Suga, H. A natural variation of fumonisin gene cluster associated with fumonisin production difference in Fusarium fujikuroi. Toxins 2019, 11, 200. [CrossRef] [PubMed]

247. Fumero, M.V.; Villani, A.; Susca, A.; Haidukowski, M.; Cimmarusti, M.T.; Toomajian, C.; Leslie, J.F.; Chulze, S.N.; Moretti, A. Fumonisin and Beauvericin Chemotypes and Genotypes of the Sister Species Fusarium subglutinans and Fusarium temperatum. Appl. Environ. Microb. 2020, 86. [CrossRef] [PubMed]

248. Glenn, A.E.; Zitomer, N.C.; Zimeri, A.M.; Williams, L.D.; Riley, R.T.; Proctor, R.H. Transformation-mediated complementation of a FUM gene cluster deletion in Fusarium verticillioides restores both fumonisin production and pathogenicity on maize seedlings. Mol. Plant Microbe Interact. 2008, 21, 87-97. [CrossRef]

249. Geiser, D.M.; Jiménez-Gasco, M.D.M.; Kang, S.; Makalowska, I.; Veeraraghavan, N.; Ward, T.J.; Zhang, N.; Kuldau, G.A.; O’Donnell, K. FUSARIUM-ID v. 1.0: A DNA sequence database for identifying Fusarium. Eur. J. Plant Pathol. 2004, 110, 473-479. [CrossRef]

250. Kristensen, R.; Torp, M.; Kosiak, B.; Holst-Jensen, A. Phylogeny and toxigenic potential is correlated in Fusarium species as revealed by partial translation elongation factor 1 alpha gene sequences. Mycol. Res. 2005, 109, 173-186. [CrossRef]

251. Wang, J.; Wang, X.; Zhou, Y.; Du, L.; Wang, Q. Fumonisin detection and analysis of potential fumonisin-producing Fusarium spp. in Asparagus (Asparagus officinalis L.) in Zhejiang province of China. J. Sci. Food Agric. 2010, 90, 836-842. [CrossRef]

252. Jurado, M.; Marín, P.; Callejas, C.; Moretti, A.; Vázquez, C.; González-Jaén, M.T. Genetic variability and Fumonisin production by Fusarium proliferatum. Food Microbiol. 2010, 27, 50-57. [CrossRef]

253. Waśkiewicz, A.; Stepień, L.; Wilman, K.; Kachlicki, P. Diversity of pea-associated F. proliferatum and F. verticillioides populations revealed by FUM1 sequence analysis and fumonisin biosynthesis. Toxins 2013, 5, 488-503. [CrossRef]

254. Stępień, Ł.; Koczyk, G.; Waśkiewicz, A. FUM cluster divergence in fumonisins-producing Fusarium species. Fungal Biol. 2011, 115, 112-123. [CrossRef] [PubMed]

255. Shephard, G.S.; Sydenham, E.W.; Thiel, P.G.; Gelderblom, W.C.A. Quantitative determination of fumonisins $\mathrm{b}_{1}$ and $\mathrm{b}_{2}$ by high-performance liquid chromatography with fluorescence detection. J. Liq. Chromatogr. 1990, 13, 2077-2087. [CrossRef]

256. Rottinghaus, G.E.; Coatney, C.E.; Minor, H.C. A rapid, sensitive thin layer chromatography procedure for the detection of fumonisin $\mathrm{B}_{1}$ and $\mathrm{B}_{2}$. J. Vet. Diagn. Investig. 1992, 4, 326-329. [CrossRef] [PubMed]

257. Schneider, E.; Usleber, E.; Märtlbauer, E. Rapid Detection of Fumonisin $B_{1}$ in Corn-Based Food by Competitive Direct Dipstick Enzyme Immunoassay/Enzyme-Linked Immunofiltration Assay with Integrated Negative Control Reaction. J. Agric. Food Chem. 1995, 43, 2548-2552. [CrossRef] 
258. Plattner, R.D. Detection of fumonisins produced in Fusarium moniliforme cultures by HPLC with electrospray MS and evaporative light scattering detectors. Nat. Toxins 1995, 3, 294-298. [CrossRef]

259. Caldas, E.D.; Winter, C.K.; Daniel Jones, A.; Ward, B.; Gilchrist, D.G. Electrospray Ionization Mass Spectrometry of Sphinganine Analog Mycotoxins. Anal. Chem. 1995, 67, 196-207. [CrossRef]

260. Szurdoki, F.; Trousdale, E.; Ward, B.; Gee, S.J.; Hammock, B.D.; Gilchrist, D.G. Synthesis of protein conjugates and development of immunoassays for AAL toxins. J. Agric. Food Chem. 1996, 44, 1796-1803. [CrossRef]

261. Yu, W.; Yu, F.Y.; Undersander, D.J.; Chu, F.S. Immunoassays of selected mycotoxins in hay, silage and mixed feed. Food Agric. Immunol. 1999, 11, 307-319. [CrossRef]

262. Gaspardo, B.; Del Zotto, S.; Torelli, E.; Cividino, S.R.; Firrao, G.; Della Riccia, G.; Stefanon, B. A rapid method for detection of fumonisins $\mathrm{B}_{1}$ and $\mathrm{B}_{2}$ in corn meal using Fourier transform near infrared (FT-NIR) spectroscopy implemented with integrating sphere. Food Chem. 2012, 135, 1608-1612. [CrossRef]

263. Man, Y.; Liang, G.; Li, A.; Pan, L. Analytical Methods for the Determination of Alternaria Mycotoxins. Chromatographia 2017, 80, 9-22. [CrossRef]

264. Mirasoli, M.; Buragina, A.; Dolci, L.S.; Simoni, P.; Anfossi, L.; Giraudi, G.; Roda, A. Chemiluminescence-based biosensor for fumonisins quantitative detection in maize samples. Biosens. Bioelectron. 2012, 32, $283-287$. [CrossRef] [PubMed]

265. Zangheri, M.; Di Nardo, F.; Anfossi, L.; Giovannoli, C.; Baggiani, C.; Roda, A.; Mirasoli, M. A multiplex chemiluminescent biosensor for type B-fumonisins and aflatoxin $\mathrm{B}_{1}$ quantitative detection in maize flour. Analyst 2015, 140, 358-365. [CrossRef]

266. Shu, M.; Xu, Y.; Wang, D.; Liu, X.; Li, Y.; He, Q.; Tu, Z.; Qiu, Y.; Ji, Y.; Wang, X. Anti-idiotypic nanobody: A strategy for development of sensitive and green immunoassay for Fumonisin B 1 . Talanta 2015, 143, 388-393. [CrossRef] [PubMed]

267. Di Nardo, F.; Alladio, E.; Baggiani, C.; Cavalera, S.; Giovannoli, C.; Spano, G.; Anfossi, L. Colour-encoded lateral flow immunoassay for the simultaneous detection of aflatoxin $\mathrm{B}_{1}$ and type-B fumonisins in a single Test line. Talanta 2019, 192, 288-294. [CrossRef] [PubMed]

268. Hou, S.; Ma, J.; Cheng, Y.; Wang, H.; Sun, J.; Yan, Y. Quantum dot nanobead-based fluorescent immunochromatographic assay for simultaneous quantitative detection of fumonisin B1, dexyonivalenol, and zearalenone in grains. Food Control 2020, 117. [CrossRef]

269. Ferrara, M.; Logrieco, A.F.; Moretti, A.; Susca, A. A loop-mediated isothermal amplification (LAMP) assay for rapid detection of fumonisin producing Aspergillus species. Food Microbiol. 2020, 90. [CrossRef]

270. Wigmann, É.F.; Meyer, K.; Cendoya, E.; Maul, R.; Vogel, R.F.; Niessen, L. A loop-mediated isothermal amplification (LAMP) based assay for the rapid and sensitive group-specific detection of fumonisin producing Fusarium spp. Int. J. Food Microbiol. 2020, 325. [CrossRef] [PubMed]

271. Bluhm, B.H.; Flaherty, J.E.; Cousin, M.A.; Woloshuk, C.P. Multiplex polymerase chain reaction assay for the differential detection of trichothecene- and fumonisin-producing species of Fusarium in cornmeal. J. Food Protect. 2002, 65, 1955-1961. [CrossRef]

272. Kim, N.Y.; Lee, I.; Ji, G.E. Reliable and simple detection of ochratoxin and fumonisin production in black Aspergillus. J. Food Protect. 2014, 77, 653-658. [CrossRef] [PubMed]

273. Nagaraj, D.; Adkar-Purushothama, C.R.; Marikunte Yanjarappa, S. Multiplex PCR for the early detection of fumonisin producing Fusarium verticillioides. Food Biosci. 2016, 13, 84-88. [CrossRef]

274. Gareis, M.; Bauer, J.; Thiem, J.; Plank, G.; Grabley, S.; Gedek, B. Cleavage of Zearalenone-Glycoside, a "Masked" Mycotoxin, during Digestion in Swine. J. Vet. Med. Ser. B 1990, 37, 236-240. [CrossRef]

275. Berthiller, F.; Maragos, C.M.; Dall'Asta, C. Introduction to masked mycotoxin. In Masked Mycotoxins in Food: Formation, Occurrence and Toxicological Relevance; Dall'Asta, C., Berthiller, F., Eds.; Royal Society of Chemistry: Cambridge, UK, 2015; pp. 1-8.

276. Liu, J.; Applegate, T. Zearalenone (ZEN) in Livestock and Poultry: Dose, toxicokinetics, toxicity and estrogenicity. Toxins 2020, 12, 377. [CrossRef] [PubMed]

277. Ekwomadu, T.I.; Dada, T.A.; Nleya, N.; Gopane, R.; Sulyok, M.; Mwanza, M. Variation of Fusarium free, masked, and emerging mycotoxin metabolites in maize from Agriculture Regions of South Africa. Toxins 2020, 12, 149. [CrossRef]

278. Crews, C.; MacDonald, S.J. Natural occurrence of masked mycotoxins. In Issues in Toxicology; Berthiller, F., Dall'Asta, C., Eds.; Royal Society of Chemistry: Cambridge, UK, 2016; pp. 14-31. [CrossRef] 
279. Bryła, M.; Roszko, M.; Szymczyk, K.; Jedrzejczak, R.; Obiedziński, M.W. Fumonisins and their masked forms in maize products. Food Control 2016, 59, 619-627. [CrossRef]

280. Falavigna, C.; Cirlini, M.; Galaverna, G.; Dall'Asta, C. Masked fumonisins in processed food: Co-occurrence of hidden and bound forms and their stability under digestive conditions. World Mycotoxin J. 2012, 5, 325-334. [CrossRef]

281. Latorre, A.; Dagnac, T.; Lorenzo, B.F.; Llompart, M. Occurrence and stability of masked fumonisins in corn silage samples. Food Chem. 2015, 189, 38-44. [CrossRef] [PubMed]

282. Generotti, S.; Cirlini, M.; Dall'Asta, C.; Suman, M. Influence of the industrial process from caryopsis to cornmeal semolina on levels of fumonisins and their masked forms. Food Control 2015, 48, 170-174. [CrossRef]

Publisher's Note: MDPI stays neutral with regard to jurisdictional claims in published maps and institutional affiliations.

(C) 2020 by the authors. Licensee MDPI, Basel, Switzerland. This article is an open access article distributed under the terms and conditions of the Creative Commons Attribution (CC BY) license (http://creativecommons.org/licenses/by/4.0/). 